Hydrology and Earth System Sciences, 9(6), 621-644 (2005) C EGU

\title{
Hydrochemical heterogeneity in an upland catchment: further characterisation of the spatial, temporal and depth variations in soils, streams and groundwaters of the Plynlimon forested catchment, Wales
}

\author{
P. Shand ${ }^{1}$, A.H. Haria ${ }^{2}$, C. Neal ${ }^{2}$, K.J. Griffiths ${ }^{1}$, D.C. Gooddy ${ }^{1}$, A.J. Dixon ${ }^{2}$, T. Hill ${ }^{2}$, \\ D.K. Buckley ${ }^{1}$ and J.E. Cunningham ${ }^{1}$
}

${ }^{1}$ British Geological Survey, Maclean Building, Crowmarsh Gifford, Wallingford, Oxfordshire, OX10 8BB, UK

${ }^{2}$ Centre for Ecology and Hydrology, Maclean Building, Crowmarsh Gifford, Wallingford, Oxfordshire, OX10 8BB, UK

Email for corresponding author: psd@bgs.ac.uk

\begin{abstract}
The heterogeneous nature of upland hard-rock catchments in terms of geology, geomorphology, superficial deposits, soil type and land use gives rise to a range of hydrochemical characteristics in stream waters. This is further complicated by the large and often rapid changes in stream flow typical of storm events. The sources of solutes and flow pathways in hard-rock catchments are still poorly understood, in particular the role of bedrock groundwater. Spatial variations in water chemistry are presented for stream waters, soils and groundwaters in the forested Plynlimon catchment of Wales, UK. The results highlight a large degree of spatial heterogeneity in each of these systems. This has major implications for the application of end-member mixing analysis and presents serious problems for modelling in scaling up from study sites to catchment scale. However, such data provide important constraints on sources, flow pathways and residence times within individual catchment compartments, knowledge of which is essential for understanding how such catchments function. The characterisation of sub-surface waters in upland catchments requires a great deal of care during sampling as well as high spatial and temporal resolution of sampling, and further work is required to characterise the Plynlimon catchments fully. Nevertheless, the presence of an active and highly stratified groundwater system is considered important as a source of solutes and water to streams. It also provides a storage medium that is likely to make a major contribution to explaining the strongly damped rainfall $\mathrm{Cl}$ and $\delta^{2} \mathrm{H}$ signals measured in the streams.
\end{abstract}

Keywords: Plynlimon, groundwater, streams, catchment, hydrochemistry, heterogeneity, forestry, surface-ground water interaction

\section{Introduction}

The interactions between soil water, stream water and groundwater are poorly understood in upland catchments, despite a plethora of models able to reproduce specific outputs. One of the main problems with modelling upland catchment systems is the large degree of spatial and temporal heterogeneity which, typically, exists even in relatively simple geological systems. The sustainability of stream and riparian ecosystems and biomass production may, however, be critically dependent on the cycling and flux of water and solutes between these compartments.

Hydrochemical methods have been successful in the development of models for streamflow generation, particularly in western Europe and North America
(Christopherson et al., 1994). However, ambiguities have arisen because of the non-conservative nature of most solutes and, for those typically assumed conservative (e.g. Cl), the difficulties of assessing input functions e.g. the contributions of dry or occult deposition and biomass cycling. The stable isotopes of water $\left(\delta^{2} \mathrm{H}\right.$ and $\left.\delta^{18} \mathrm{O}\right)$ represent the only truly conservative tracers of water and have been very successful at event scales in showing that pre-event water often forms a major component of storm runoff (see Genereux and Hooper, 1998, for summary). The source of this pre-event storage, however, remains controversial.

The combination of relatively high rainfall, low temperatures, steep slopes and thin, often base-poor, soils make many parts of upland Britain susceptible to soil 
acidification and low-pH runoff (Cresser et al., 1986). Several studies in upland Wales have highlighted the importance of overland flow and pipe flow as contributors to stormflow (Muscutt et al., 1993; Soulsby, 1992). However, much of this work has concentrated on small headwater tributaries with catchment areas of a few hectares in peat-dominated parts of the catchment. The transient movement of water through soils has been shown to be important in several studies (Chappell et al., 1990; Soulsby and Reynolds, 1992). Soulsby (1992) monitored soils in the Llyn Brianne catchment of Wales and noted that soils remained unsaturated during storm events, the exception being saturated soils on the lower slopes of the catchment. It was suggested that transient lateral movement of water at the base of soils above impermeable bedrock towards the stream channel was an important flow pathway. Strongly damped signals of natural atmospheric tracers in upland catchments imply that pre-event water dominates during peak stream flow; Soulsby (1995a) showed that as much as $75 \%$ of storm runoff was from pre-event water.

End member mixing analysis (EMMA) has proved useful in developing models of streamflow generation. Difficulties with EMMA include determining end-member compositions and variations, and assuming that the source of a particular solute is the source of the water itself. There is a need to validate such assumptions or to use tracers which are either conservative or part of the water molecule itself to provide a more valid approach to mixing models. Christopherson et al. (1990) showed that the composition of stream waters in the Plynlimon and Birkenes catchments could not be explained by the mixing of identified soil water endmembers. Hooper et al. (1990) showed that groundwater is an important component in the Panola catchment but the heterogeneity of groundwaters made end member identification difficult. Groundwater also accounts for 50$60 \%$ of total annual runoff from an upland grantitic catchment in Scotland, (Soulsby et al., 1998).

The role of groundwater in upland areas is perhaps the least understood aspect of water transfer through catchments, largely because many such catchments have traditionally been considered to be impermeable at the base of the soils. However, it is becoming increasingly apparent that many upland catchments, previously considered to be underlain by impermeable bedrock, contain groundwater which may play an important role in streamflow generation (Shand et al., 1997; Neal et al., 1997a; McGlynn et al., 2002; McDonnel, 2003; Haria and Shand, 2004). In such areas, the discharge of groundwater to streams or soils may represent an important flux of solutes and nutrients supporting surface and near-surface ecosystems.

The presence of groundwater in fractured Lower Palaeozoic bedrock in Wales, previously considered impermeable, has recently been shown to be widespread in central and southern Wales (Shand et al., 2005), but detailed catchment scale studies are lacking (Neal et al., 1997a; Haria and Shand, 2004). This paper presents new data on soils, stream waters and groundwaters in the Plynlimon forested catchment in Wales (Fig. 1) and highlights the spatial
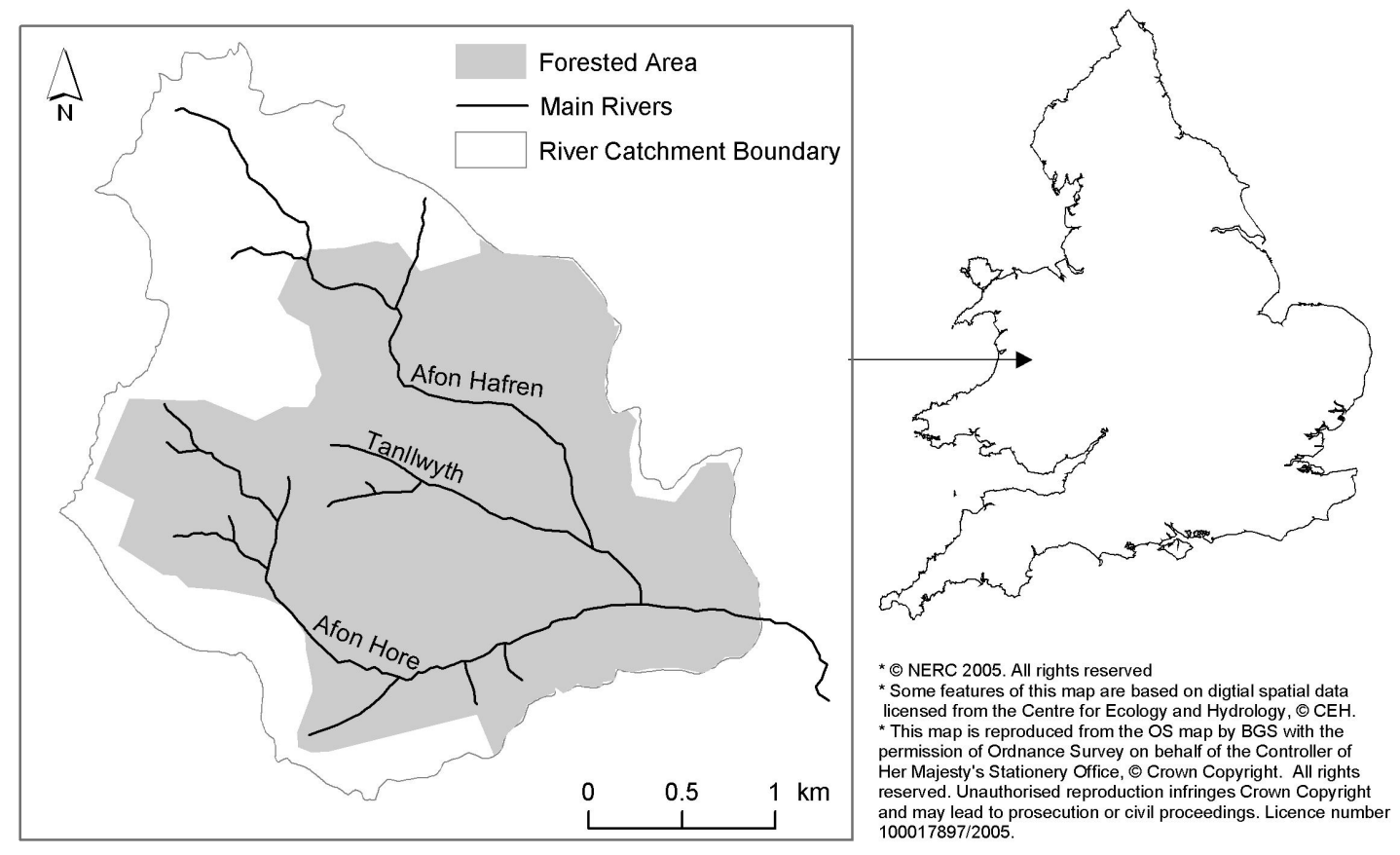

Fig. 1. Location of the forested Hafren catchment, Plynlimon. 
variations in stream water chemistry, soil porewater chemistry and temporal and depth variations of groundwater in the catchment. The consistency of variations in space and time are obviously important in assessing the degree of confidence in models for such upland catchments. The limitations of existing data in characterising the groundwater system will also be discussed.

\section{The Plynlimon catchments}

The Plynlimon catchments in Wales are approximately $25 \mathrm{~km}$ northeast of Aberystwyth (Fig. 1). Detailed information on the catchments and on the early history of research in the catchments has been presented by Kirby et al. (1991) and Neal (1997).

Early catchment-scale rainfall-runoff models were effective in predicting the physical response of streams to rainfall events (Kirby et al., 1991). The hydrochemistry of catchment inputs (precipitation, dry deposition, etc.) and outputs (stream waters collected at flumes) in the forested catchments were also studied in some detail (Neal et al., 1990). Hydrochemical data have been invaluable in constraining conceptual models with regard to potential flow pathways through the catchment. This has been based largely on the monitoring of selected sites, highlighting the temporal variations related to changing atmospheric inputs and the effects of changes in land use (afforestation and deforestation). Neal et al. (1990) showed that stream waters change from relatively base-rich alkaline waters at baseflow to base-poor and acidic at high flow. Storm flow waters are typically depleted in base cations and enriched in $\mathrm{Al}$ and DOC (Neal et al., 1990).

Large atmospheric variations in $\mathrm{Cl}$ were found to be strongly damped in streams (Neal and Rosier, 1990). Research on the stable isotopes of hydrogen $\left(\delta^{2} \mathrm{H}\right)$, a component of the water molecule itself, also found that variations in rainfall chemistry were strongly damped (Neal and Rosier, 1990; Sklash et al., 1996). Such data imply that a significant amount of storage exists in the catchment and that a simple rainfall-runoff model cannot explain the internal workings and flowpaths of water in the catchment. Chemical fingerprinting of sources using EMMA were used to elucidate flow pathways (Wade et al., 1999; Burns et al., 2001). Mixing models were thus developed, initially between shallow and deep soils (Neal et al., 1990). More recent work (Neal et al., 1997a; Shand et al., 1997; Haria and Shand, 2004) has highlighted the presence of groundwater within the bedrock beneath the soils, and may provide an important component of stream flow. These preliminary conclusions were supported by fractal studies using $\mathrm{Cl}$ input-output concentrations (Kirchner et al., 2001).
These studies confirm that a range of travel times is required to describe the stream $\mathrm{Cl}$ signal, even in catchments which show a flashy response to rainfall inputs.

The damping effect noted for conservative solutes and stable isotope studies showed that not only is there significant storage within the catchment but also that much of the storm hydrograph is pre-event water. Although conceptual models do exist for fractured aquifers (Mather, 1985), these have tended to focus on deeper fractures; studies of very shallow $(<30 \mathrm{~m})$ systems which respond to individual rainfall events (e.g. Haria and Shand, 2004; Shand et al., 2004) are lacking. Groundwater flow paths in upland catchments are likely to be dominated by flow towards the stream channel, but complexities arise due to heterogeneities in the soil and bedrock such as fracture density, spacing and connectivity. A detailed deterministic model is required to produce a model capable of quantifying the role of groundwater in stream flow generation in such catchments.

\section{Site details, sampling and analytical techniques}

The Afon Hafren and Afon Hore catchments, the two main headwater sub-catchments of the river Severn, are of similar size, about 340 ha, with elevations of $350-750 \mathrm{~m}$ above sealevel (see Fig. 1). Both are largely forested, mainly with Sitka spruce but with semi-natural moorland in the upper reaches above the tree line. In different parts of the catchments, the forest has been cleared and replanted recently. Mean annual temperature is $7.2^{\circ} \mathrm{C}$ and rainfall in the area is around $2500 \mathrm{~mm}$, nearly $75 \%$ of which is derived from synoptic westerly air masses. The area has been influenced strongly by the effects of Quaternary glaciation and periglaciation (Newson, 1976). Valleys are typically steep but there are also some flat valley areas with alluvial reaches (Kirby et al., 1991).

Lower Palaeozoic mudstones and shales dominate the bedrock geology with minor sandstones and grits present in the headwaters of the catchment. The upper part of the catchment comprises the Ordovician Fan shales, a series of blue-grey mudstones and shales which are well exposed, forming competent outcrops in the stream channel. The upper part of this sequence is the Rhaeder mudstone, a thick resistant band which forms a waterfall (Blaen Hafren) separating it from the younger Silurian Gwestyn Shales further downstream. The Gwestyn Shales are grey to black shales and mudstones, locally containing abundant pyrite. The mineralogy of the mudstones comprises an iron magnesium chlorite, a dioctahedral mica and quartz, with lesser amounts of feldspar and iron oxides (Hornung et al., 1986).

The catchment is covered with thin $(0.5-1.0 \mathrm{~m})$ acidic 
soils, mainly podzol in the free draining areas and peat on the flat upper parts and wider interfluves (Kirby et al., 1991). Recent trenching has established the presence of well developed podzols beneath the headwater peat in the catchment. Soil mineralogy is closely related to the bedrock but with the alteration of chlorite and transformation of illite to vermiculite, particularly in the upper soils. The valley bottoms where drainage has been impeded often contain a complex of peat and gleyed mineral soils. Few data are available on the chemistry of the soils with which to assess spatial or temporal variations in pore water or exchangeable chemistry (Stevens et al., 1997).

Soil waters were extracted by centrifuging and extractions were undertaken using $\mathrm{CaCl}_{2}, \mathrm{BaCl}_{2}$ and $\mathrm{NH}_{4}$-acetetae extractions. The extractions were performed in duplicate and, for each horizon, these were bulked. The experimental procedure was as described by Gooddy et al. (1995). Three representative soils were sampled (Fig. 2); a podzol represented the freely draining slopes of the forest, a gleysol was excavated approximately $30 \mathrm{~m}$ from the Tanllwyth where gleysols are best developed, and a peat was sampled near the source of the Hafren in moorland above the forested area. Much of the peat is eroded into 'hags' and this was sampled where it rose above the adjacent peat soil pit. A Bhorizon was present immediately beneath the peat and an underlying thick Ea horizon (Fig. 2), During excavation, the soil pit filled with water rapidly so it was not possible to assess depth to bedrock.

The characterisation and interpretation of soil waters present several difficulties; sampling methods include centrifugation, zero tension and tension lysimeters and each may produce different results (Suarez, 1987; Litaor, 1988; Grossmann and Udluft, 1991; Mulder and Cresser, 1994). The choice of technique is largely dependent on the specific problem, e.g. centrifugation samples a range of pore size waters which may be better suited to weathering studies, whilst zero tension lysimeters may be more useful for sampling macropore flow. The main aim of this work is to highlight the potential degree of spatial heterogeneity of soil waters; it is accepted that care is needed when interpreting the data. Temporal variations have not been assessed.

For the stream and groundwater samples, $\mathrm{pH}$, dissolved oxygen (DO) and redox potential (Eh) were measured onsite (for the groundwaters, these were measured in a flowthrough cell). Other on-site measurements included temperature $\left({ }^{\circ} \mathrm{C}\right)$, specific electrical conductance (SEC) and alkalinity. All samples for major and trace chemical analysis were collected in polyethylene bottles. Those for major and trace elements were filtered through $0.45 \mu \mathrm{m}$ filters and the aliquots for cation and trace elements were acidified to $1 \%$ $\mathrm{v} / \mathrm{v} \mathrm{HNO}_{3}$ to minimise adsorption onto container walls. Major cations and sulphate were analysed by Inductively Coupled Plasma Atomic Emission Spectrometry (ICP AES) and a wide range of trace elements by Inductively Coupled Plasma Mass Spectrometry (ICP MS). Nitrogen species and the halogen elements $(\mathrm{Cl}, \mathrm{Br}, \mathrm{I}, \mathrm{F})$ were analysed by ion chromatography or automated colorimetry. Dissolved organic carbon (DOC) samples were collected in Cr-acid washed glass bottles after filtration through $0.45 \mu \mathrm{m}$ silvermembrane filter, and analysed by a TOCSIN II analyser.
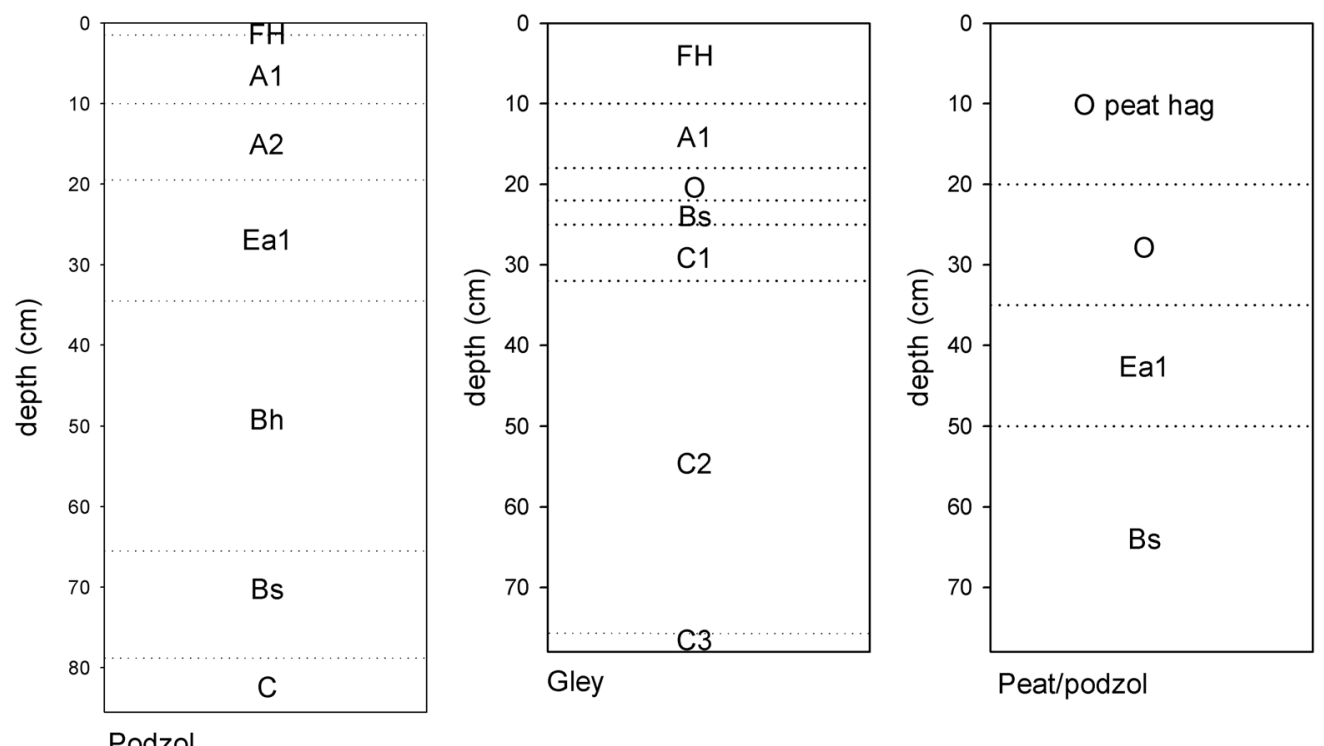

Fig. 2. Schematic soil profiles for the Podzol, Gley and Peat soils studied. 


\section{Hydrochemistry of Plynlimon waters} SOILS

The soil porewater profiles are shown in Fig. 3. The podzol and gley profiles generally showed high concentrations of major cations and anions in the FH horizon due to cycling and organic complexing. The concentrations of $\mathrm{Ca}, \mathrm{Al}$ and $\mathrm{HCO}_{3}$ in the porewaters extracted were within the range of concentrations reported by Reynolds et al. (1986) for soil waters collected using suction samplers. Dissolved organic carbon (DOC) was extremely high in upper organic horizons. The $\mathrm{pH}$ increased with depth due to weathering
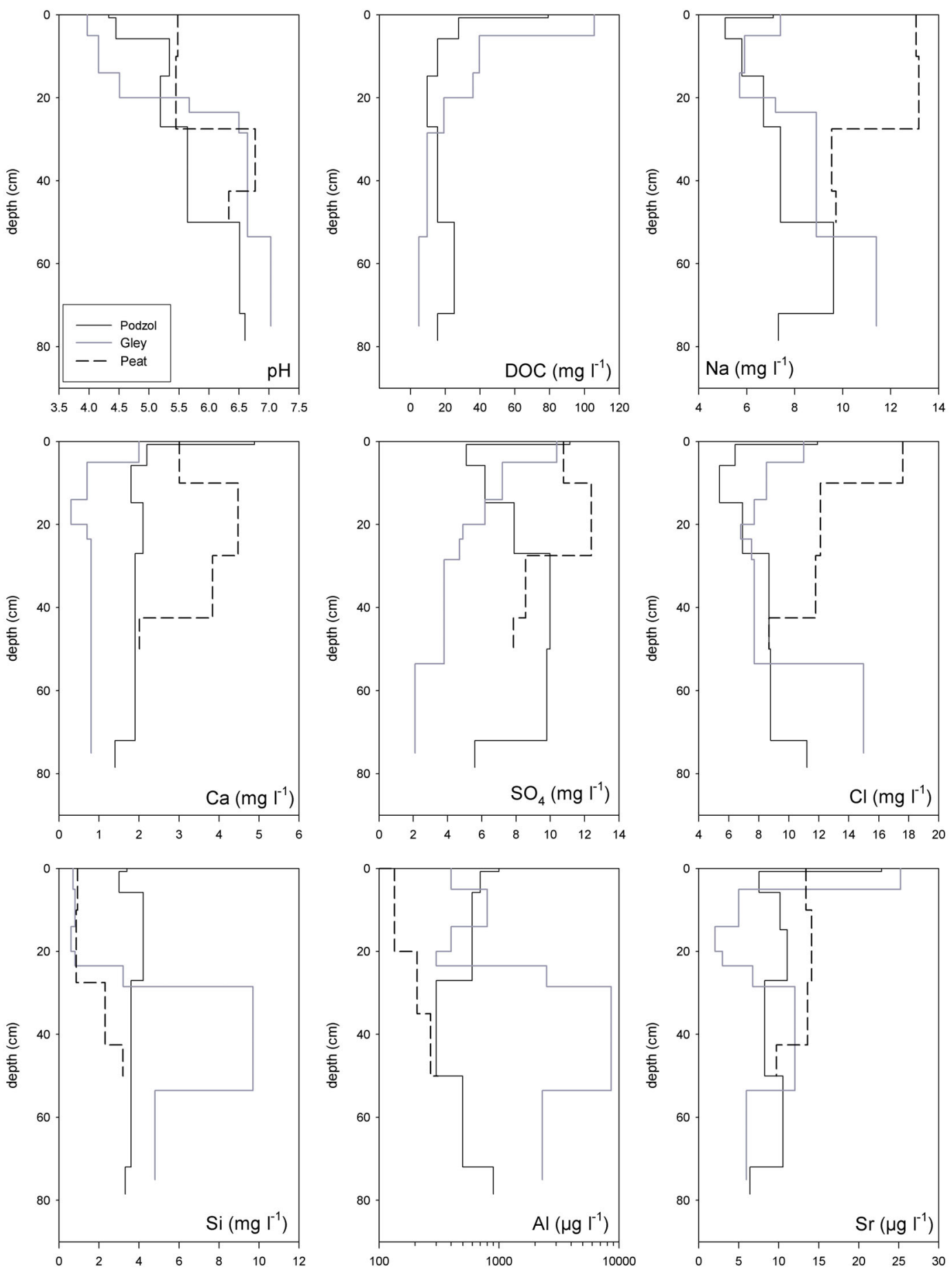

Fig. 3. Selected soil porewater chemistry for the Plynlimon soils. 
reactions and buffering in the deeper mineral horizons. However, absolute values may have been modified by degassing during extraction. The dominant cation in the mineral soils is Na which increases with depth. This increase is also reflected in $\mathrm{Cl}$ and indicates the dominant role of rainfall. The $\mathrm{Na} / \mathrm{Cl}$ ratios change from close to average rainfall $(0.59$, Neal et al., 1997b) in the upper soils to 1.2 in the mineral horizons; this indicates additional inputs from mineral weathering or ion-exchange. Such additions may account for up to $50 \%$ of the $\mathrm{Na}$ present. The $\mathrm{Na} / \mathrm{Cl}$ ratios and the concentrations of many other solutes are highest in the intermediate mineral soil horizons and decrease above the bedrock surface. Calcium concentrations were also significant, although calcite is not present, with dominant inputs derived from weathering (typically $>90 \%$ in the Podzol and $>70 \%$ in the gleysol). The importance of silicate weathering is also highlighted by relatively high $\mathrm{Si}$ and an increase in alkalinity with depth. Magnesium concentrations are generally low and dominated by atmospheric inputs. Many trace elements such as $\mathrm{Al}, \mathrm{As}, \mathrm{Be}, \mathrm{Fe}, \mathrm{Ni}, \mathrm{Rb}$ and the rare earth elements were enriched in the $\mathrm{B}$ and $\mathrm{C}$ horizons of the soils as a consequence of weathering and proton exchange. Barium reached moderately high concentrations and $\mathrm{Sr}$ and $\mathrm{Rb}$ profiles follow those of $\mathrm{Ca}$ and $\mathrm{K}$ respectively, reflecting their similar geochemical behaviour.

Each of the profiles shows considerable heterogeneity, reflecting the complex biogeochemical and weathering processes during soil formation. This has probably been enhanced by the growth of coniferous plantations. In addition to the vertical changes in porewater chemistry, differences between the soils are significant; these make it difficult to characterise soil end-member compositions. Such heterogeneity is likely to increase further with temporal variations.

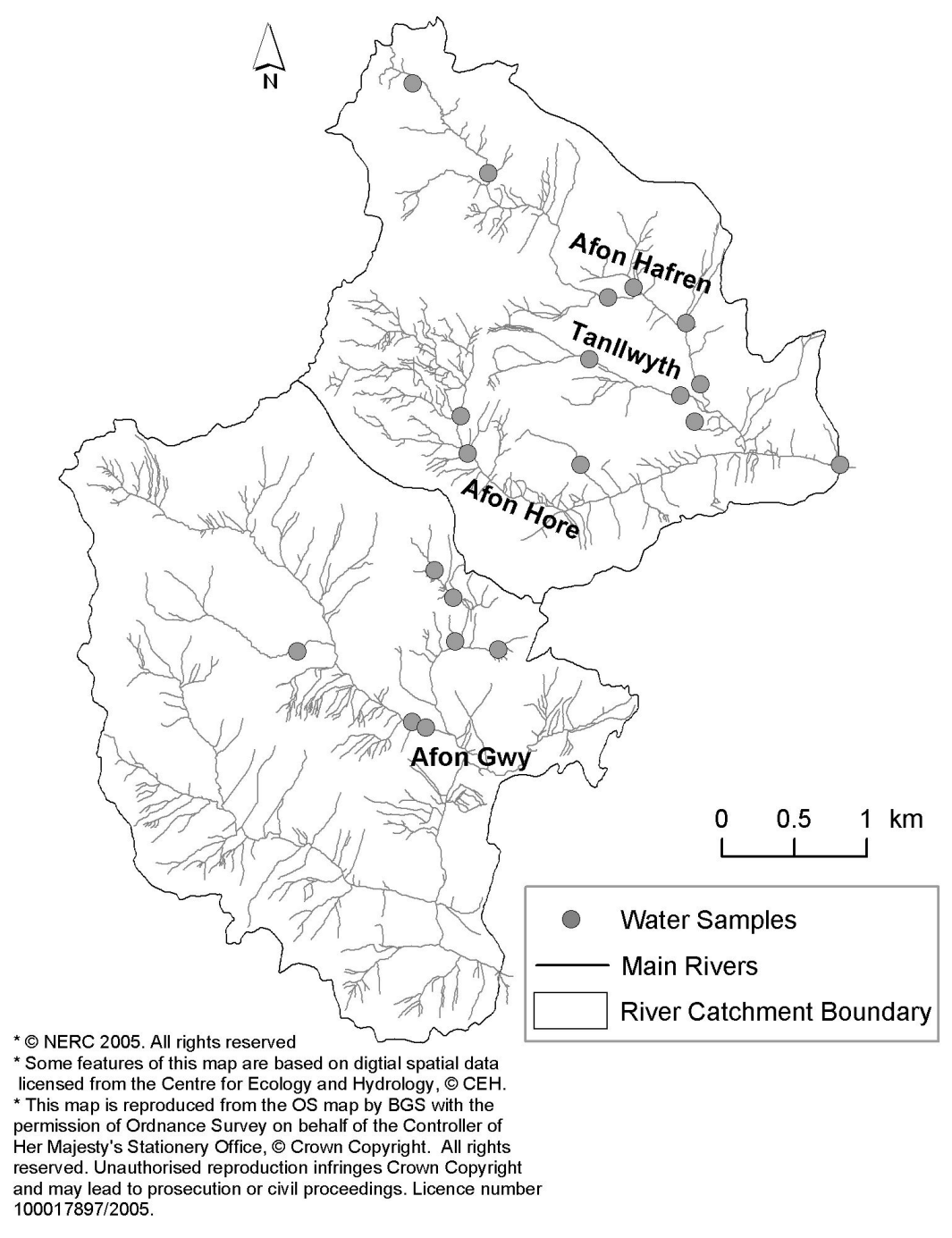

Fig. 4. Location map for stream water samples collected at baseflow and stormflow. 


\section{Streams}

\section{Spatial responses in stream water chemistry}

Stream samples were collected during low and high flow conditions from the tributaries of the Severn to assess synoptic variations and, for comparison, those in the adjacent
Wye grassland catchments (Fig. 4). The low flow data are plotted against stormflow data to assess the response of the different streams to changes in flow (Fig. 5).

There is considerable spatial variation both in hydrochemistry and in the responses to rainfall events which vary from site to site. They confirm the general changes in
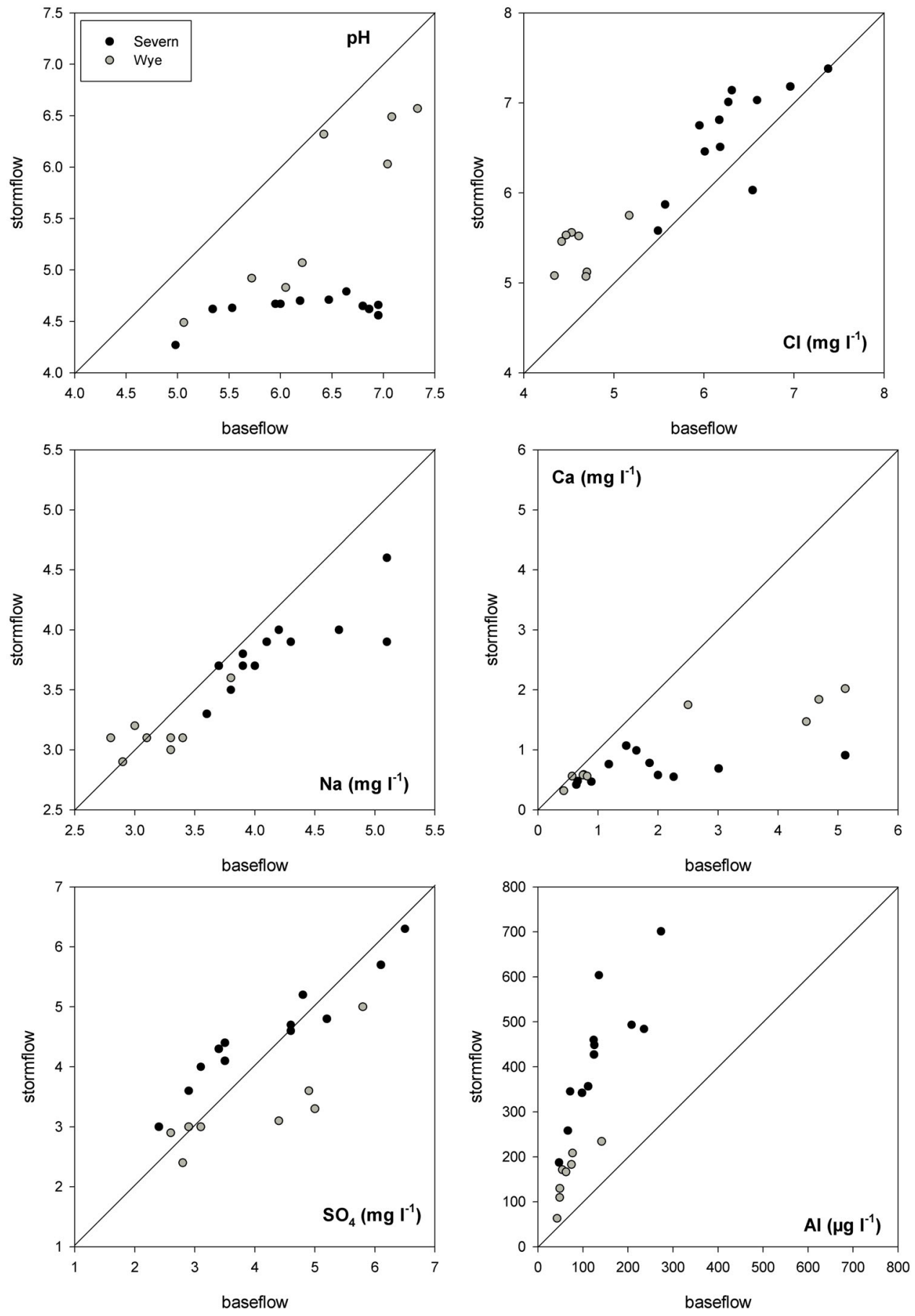

Fig. 5. Comparison of baseflow and stormflow concentrations for selected solutes in streamwaters in the Severn and Wye catchments. 
chemistry with flows monitored at the flumes (Neal et al., 1990); these varied from more alkaline during low flow to more acidic and Al-bearing at high flows. Those which maintained relatively high values of $\mathrm{pH}$ during stormflow conditions (Fig. 4) were downstream of a disused carbonatebearing $\mathrm{Pb}-\mathrm{Zn}$ mine. The largest $\mathrm{pH}$ changes occurred in the forested Severn catchment, where most streams showed a slight increase in SEC during the high flow period. There were significant differences between the Severn and Wye catchments (Fig. 5). For example, concentrations of $\mathrm{Na}, \mathrm{Cl}$ and $\mathrm{Si}$ were higher in the forested Severn catchments, probably as a function of increased evapotranspiration and/ or scavenging of sea-salts. Sulphate was also higher in the forested catchment, except in the tributary of the Wye close to the $\mathrm{Pb}-\mathrm{Zn}$ mine.

Aluminium displayed large increases in concentration at high flow (Fig. 5); the dominant control on Al concentration is the $\mathrm{pH}$ of the streamwater, with mobilisation occurring under more acidic conditions (Fig. 6). There is, however, a large difference in dissolved aluminium across the catchment, generally increasing in proportion to the concentrations under low flow conditions and concentrations of aluminium are higher in the forested catchment (Fig. 6).

The large changes in acidity, alkalinity and Al concentrations with flow are not reflected for all elements. This is especially true for $\mathrm{Na}, \mathrm{Mg}, \mathrm{Cl}, \mathrm{SO}_{4}$ and several trace metals (e.g. $\mathrm{Cu}, \mathrm{Ni}$ ). Calcium (and $\mathrm{Sr}$ ) concentrations decrease considerably at high flow. The highest $\mathrm{Sr}$ and $\mathrm{Ca}$ concentrations in the Severn catchment (Tanllwyth) are due

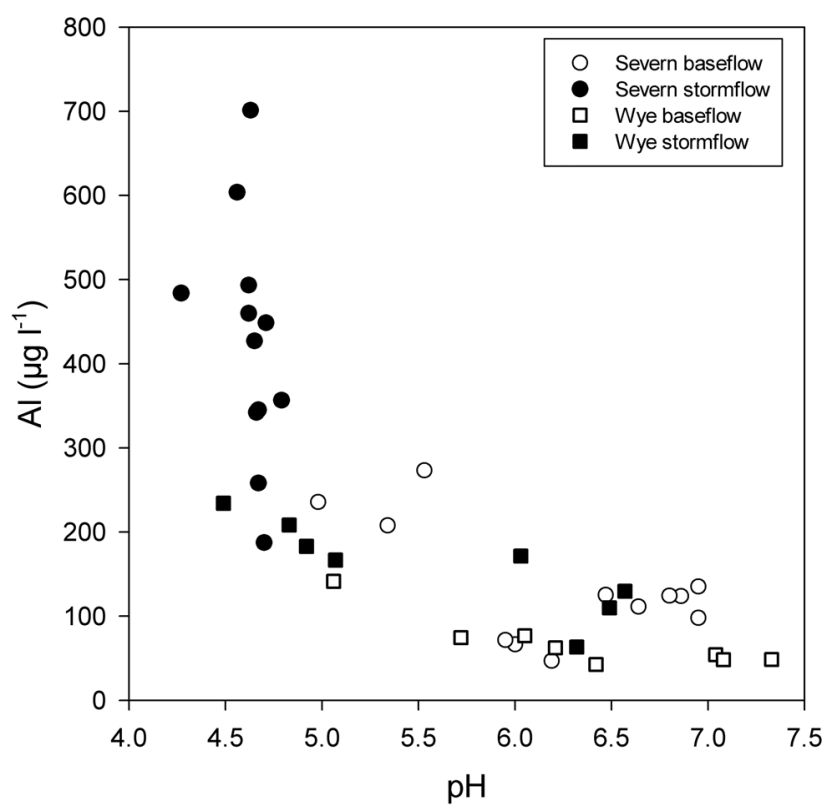

Fig. 6. Plot of Al vs. $p H$ in streamwaters of the Severn and Wye catchments. to drilling which cleared a fracture introducing groundwater into the stream and is, therefore, not representative of baseline conditions (Neal et al., 1997a). The changes in the concentrations of solutes are small compared with the large increases in flow, showing that simple dilution by rainfall cannot explain the results.

Long-term monitoring of hydrochemical stream data shows that the picture is more complex (Robson et al., 1993; Neal et al., 1997b), depending inter alia on atmospheric inputs and antecedent conditions. Nevertheless, the data highlight the large spatial variations in stream water chemistry across both catchments.

Changes in hydrochemistry along the reach of the Afon Hafren

More detailed sampling was undertaken along the reach of the Afon Hafren, during baseflow, to assess baseflow inputs between the headwater to the confluence with the Afon Hore (Fig. 7). Samples from the Tanllwyth and three small tributaries which flowed into the Afon Hafren were also collected. The results are plotted in Fig. 8 against distance from the "source of the Hafren". The SEC decreased, initially, but then increased by a relatively small amount as

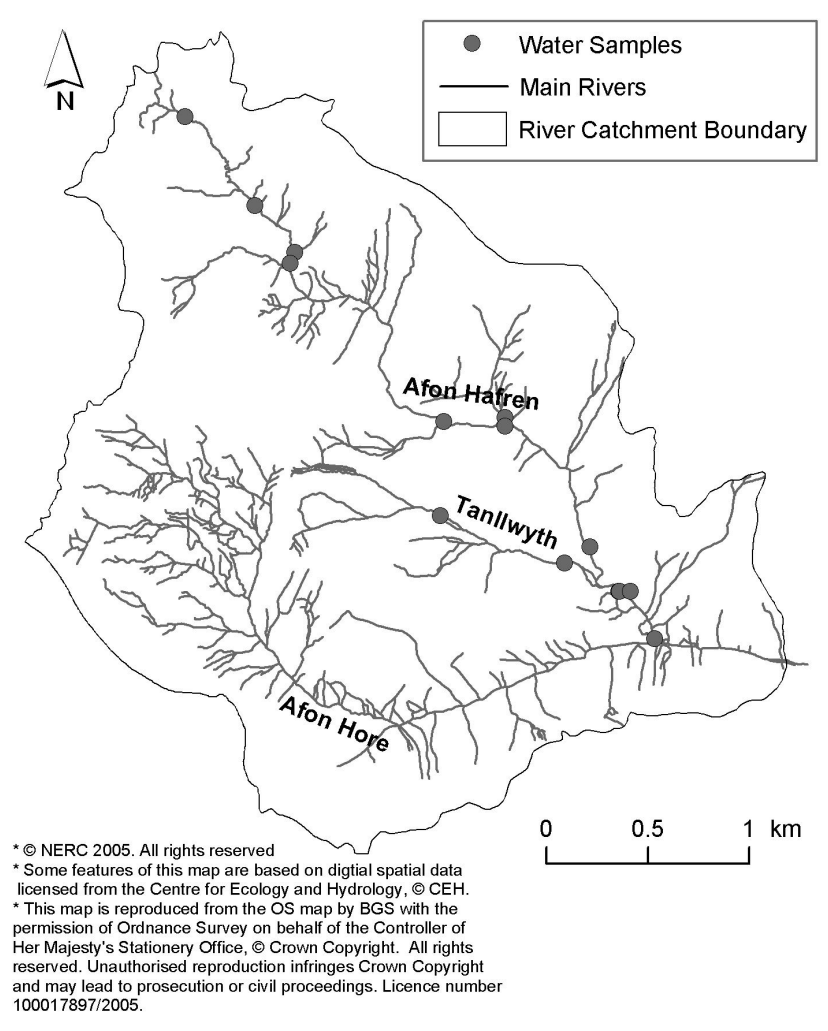

Fig. 7. Location of samples collected for Afon Hafren reach study. 
Hydrochemical heterogeneity in the soils, streams and groundwaters of the Plynlimon forested catchment, Wales
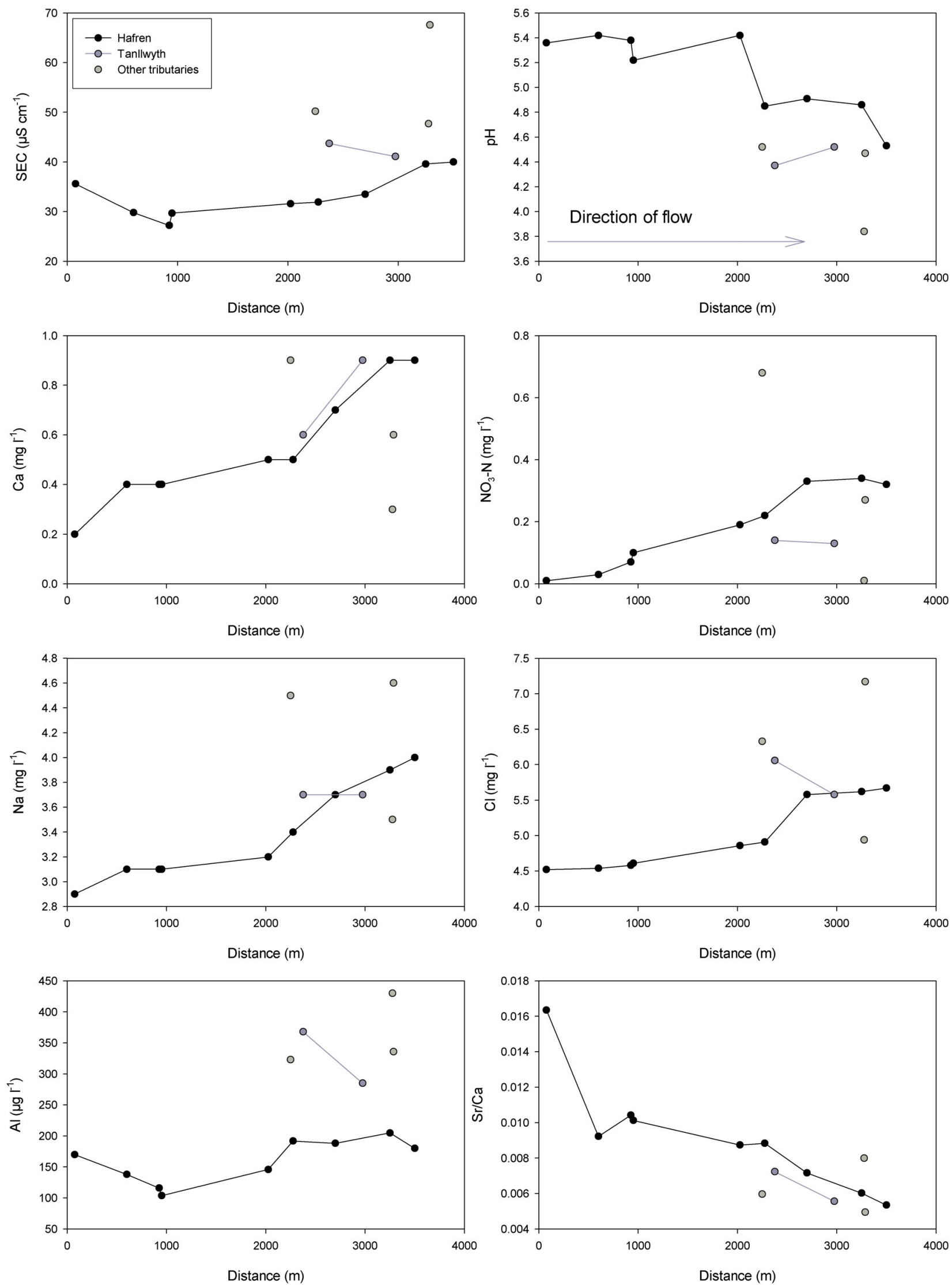

Fig. 8. Changes in chemistry downstream from the headwater of the Afon Hafren to the confluence with the Afon Hore for selected elements. 
the stream flowed through the forested area; hence, SEC appears to be a relatively poor indicator of hydrochemical changes within the reach. The $\mathrm{pH}$ decreased slightly downstream but was typically more alkaline than the smaller tributaries, which were more typical of acidic soil waters. Concentrations of major cations and anions generally increased downstream (Fig. 8), with the steepest increase in $\mathrm{Ca}, \mathrm{Mg}, \mathrm{Na}$ and $\mathrm{SO}_{4}$ occurring downstream of the junction between the Ordovician Fan shales and the Silurian Gwestyn shales. The halogen elements $\mathrm{Cl}$ and $\mathrm{Br}$ showed a slight increase from the headwaters downstream and a more dramatic increase close to, but upstream of, the confluence with the Tanllwyth. The major element chemistry of the Tanllwyth was similar to that of the Hafren at the time of sampling, in contrast to that of the other tributaries, the chemistries of which were very variable.

Nitrate concentrations increased downstream, showing a relatively uniform increase (Fig. 8). Trace elements also showed significant variations. Initially, aluminium decreased downstream in the grassland but increased in the forested part of the catchment (Fig. 8). Strontium increased in a similar manner to $\mathrm{Ca}$. The ratios $\mathrm{Sr} / \mathrm{Ca}$ and $\mathrm{Mg} / \mathrm{Ca}$, both useful for determining end-member compositions, decreased downstream from rainfall/seawater ratios to values similar to deeper soils and groundwaters. As with the major elements, the trace components in the tributaries were heterogeneous, in general being higher due to increased mobility under the more acidic conditions of these streams.

The changes in the baseflow chemistry of the main Hafren stream point towards an increasing weathering-derived (e.g. higher $\mathrm{Ca}, \mathrm{Mg}, \mathrm{Si}$ ) component downstream. The changes are not constant, however, probably reflecting different inputs along the stream reach. The greatest change coincides with a change in bedrock geology, a flattening of the valley bottom and the presence of fluvial gravel deposits in parts of the stream channel, all of which may be important controls on sub-surface flow.

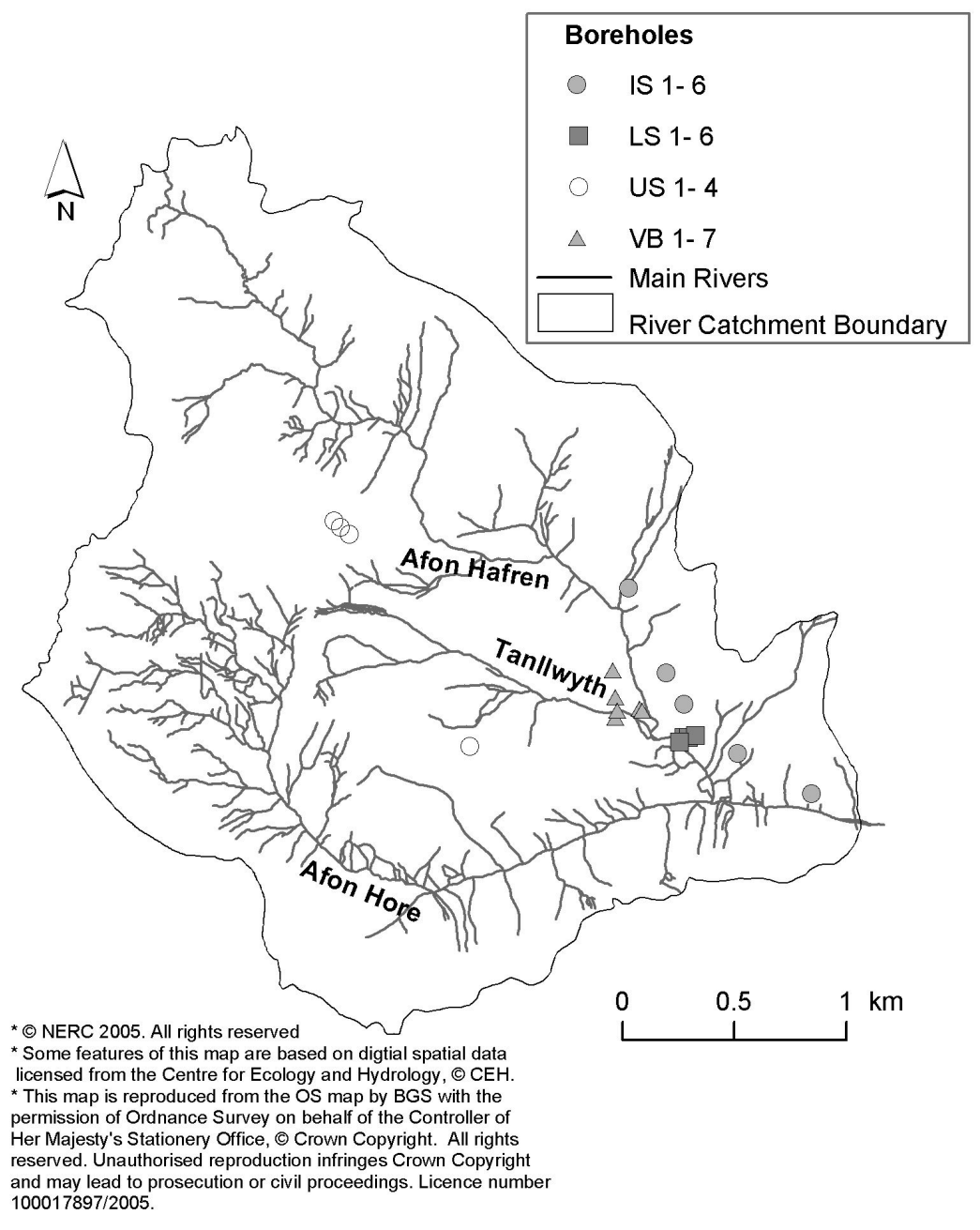

Fig. 9. Map showing the location of boreholes drilled in the catchment. 
Table 1. Depths of boreholes sampled in the Hafren catchment

\begin{tabular}{cl}
\hline Borehole & depth $(\mathrm{m})$ \\
\hline Upper slope & \\
US 1 & 2.7 \\
US3 & 14.1 \\
US4 & 27.5 \\
Intermediate slope & \\
IS1 & 10.2 \\
IS2 & 15.8 \\
IS3 & 9.2 \\
IS5 & 8.4 \\
IS6 & 8.5 \\
& \\
Lower slope & \\
LS1 & 6.4 \\
LS2 & 7.4 \\
LS3 & 8 \\
LS4 & 11 \\
LS6 & 44.5 \\
Valley bottom & \\
VB1 & 11 \\
VB2 & 47.4 \\
VB3 & 44.4 \\
VB4 & 7 \\
VB5 & 16 \\
\hline
\end{tabular}

\section{GROUNDWATER}

A series of boreholes from $2.7 \mathrm{~m}$ to $47 \mathrm{~m}$ in depth was drilled into the bedrock of the Afon Hafren catchment (Fig. 9) from the upper slopes down to the valley bottom (Neal et al., 1997a). (Table 1). All boreholes struck groundwater regardless of depth or location in the catchment. The boreholes are grouped according to location in the catchment: upper slopes close to the edge of the forest (US 1-3) and on the interfluve (US 4), intermediate valley slopes (IS 1-6), lower slopes (LS 1-6) close to the lower Hafren, and valley bottom boreholes in the flat-lying area near the confluence of the Hafren and Tanllwyth (VB 1-3). Alluvial gravels (up to $7 \mathrm{~m}$ depth and cased off) were present in the area where VB 1 and VB 2 were drilled. Three deep boreholes (LS 6, VB 2, VB3) were drilled to depths of c. $45 \mathrm{~m}$ and cased to depths of c. $5 \mathrm{~m}$, being open below this depth.

Geophysical logging in the deep boreholes was completed and showed that groundwater occurs in discrete fractures. Temperature and SEC varied with depth (Buckley, 2000; Shand et al., 1999), indicating a highly stratified system in terms of flow and chemistry, with limited contact between shallow and deep fractures (Fig. 10). The location of groundwater-bearing fractures was indicated by logging flow, temperature and SEC profiles. Geological observations in the catchment showed that the deeper discontinuities represent bedding plane fractures. Vertical to sub-vertical faulting and jointing were also noted at some outcrops connecting shallow and deep fractures. The shallowest part of the bedrock represents a series of highly fractured and weathered zones explaining the stepwise decrease in SEC and $\mathrm{T}\left({ }^{\circ} \mathrm{C}\right)$, indicating an active hydrological system down to $c .10 \mathrm{~m}$ depth (Fig. 10). However, the shallowest parts of the bedrock (above c. $5 \mathrm{~m}$ depth), which may be important as a major flow path, were cased off.

No hydrogeological studies have yet been completed on the fractured aquifer but water levels were monitored monthly for a year (Fig. 11). The water levels varied seasonally and with location in the catchment. They were highest in winter, reflecting increased rainfall. These fluctuations confirm that there is active recharge and discharge in the groundwater system and that the driving heads are from the higher parts of the catchment towards the valley bottoms. The highest fluctuations in water level occurred in the upper boreholes where groundwater levels are deeper, followed by the intermediate boreholes. The lower slopes and valley bottoms, where water levels are shallow, showed little change. One of the deep valley bottom boreholes (VB 3) was continually artesian whilst some shallow ones (e.g. LS2) became artesian during heavy rainfall, especially in winter (Fig. 11).

\section{Hydrochemical variations in the deep boreholes}

Discharge and depth samples were collected during pumping and geophysical logging of the deep boreholes LS 6, VB 2 and VB 3. The intermediate depth borehole (US 4, $27 \mathrm{~m}$ deep), at the catchment divide with the Afon Hore, was studied for comparison. Water levels in the boreholes were around $10 \mathrm{~m}$ for US 4, 2-3 m for LS 6, 2-2.5 $\mathrm{m}$ for VB 2 and VB 3 was artesian. Flowing water could be heard in US 4 as water entered the borehole from a fracture above the standing water level.

Selected data are plotted in Fig. 12, where discharge samples are plotted at the top of each graph. Depth samples were collected from above the fractures as indicated by geophysical logs. Each sample probably represents a mixture of waters from different fractures due to upward well bore flow from the deeper fractures. The SEC and concentrations of dissolved components tended to be much lower in pumped discharge than depth samples (Fig. 12), especially for VB 2, indicating that the discharge was being diluted by water from shallow fractures, highlighting the need for sampling from single or nested piezometers. There are differences in the groundwater chemistry between the different boreholes 


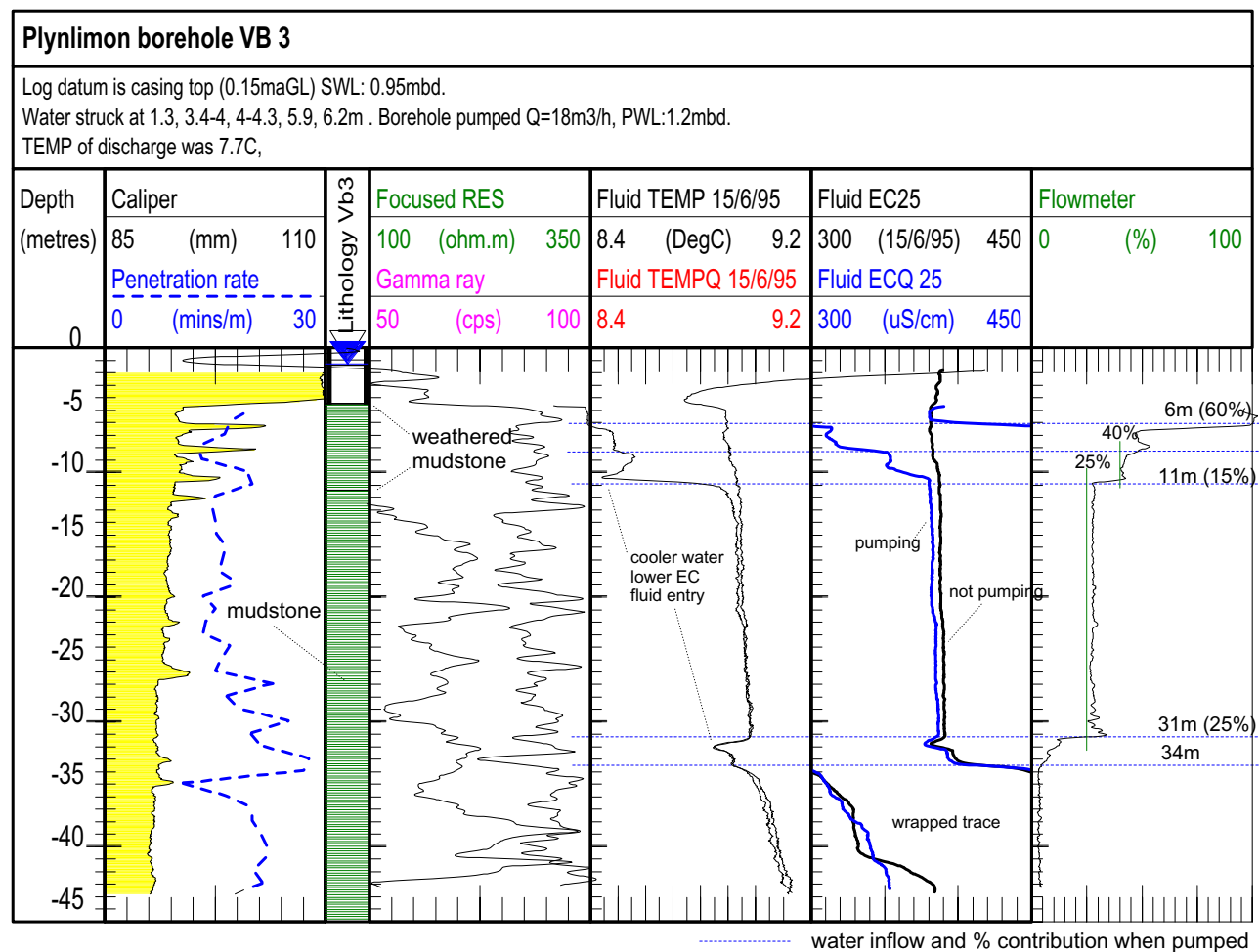

Fig. 10. Geophysical log for valley bottom borehole. Inflows are deduced using the calliper log (left), flow log (right) and changes in temperature (Fluid TEMP) and specific electrical conductance (Fluid EC25).

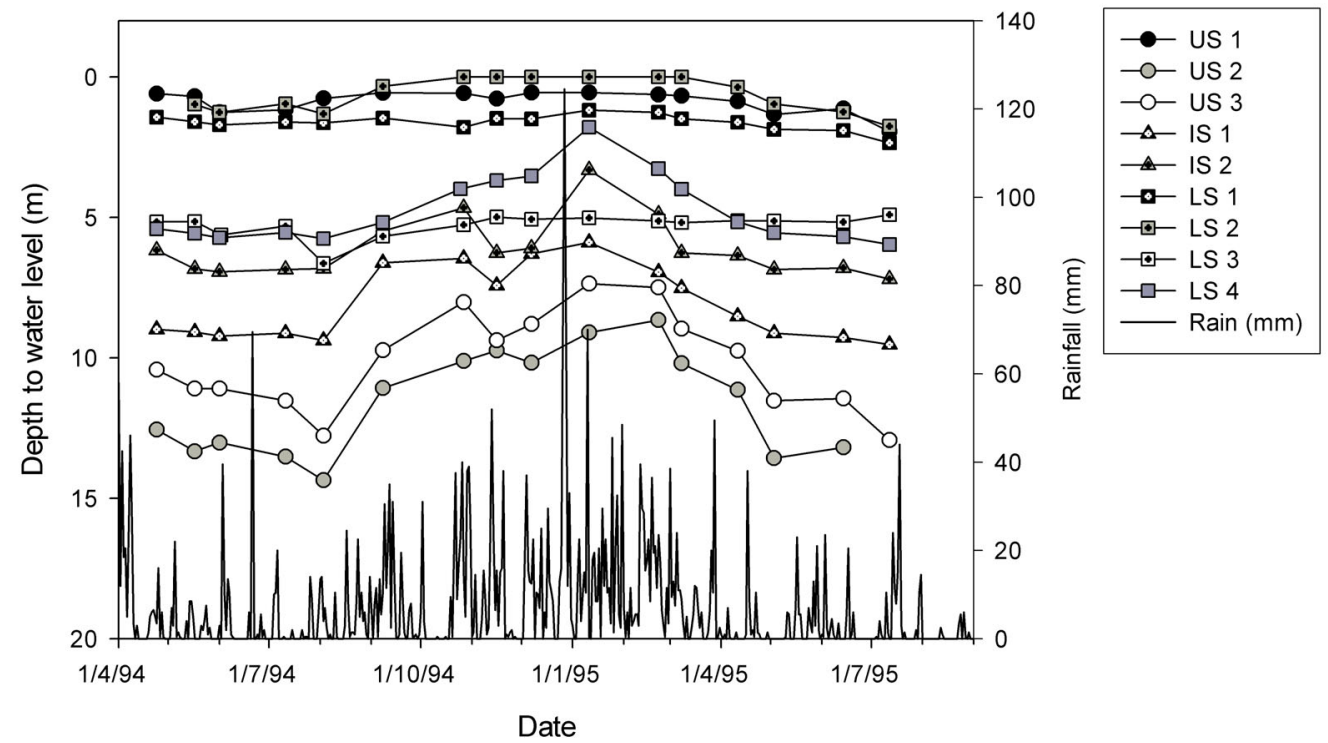

Fig. 11. Water levels measured monthly in the shallow boreholes for one year. Rainfall during the period is also plotted for comparison.

which highlight spatial differences in the scale and type of chemical weathering. In general, most boreholes showed an increase in the concentrations of major elements with depth. Highest SEC groundwater occurred in the boreholes in the valley bottom with high concentrations of $\mathrm{Ca}, \mathrm{Mg}$ and $\mathrm{HCO}_{3}$. Potassium concentrations were low in the upper slope borehole but remarkably similar in the valley bottom and lower slope boreholes. Sulphate, on the other hand, was much lower in the valley bottom boreholes. The groundwater in borehole VB 2 had low $\mathrm{Cl}$ concentrations $\left(<4 \mathrm{mg} \mathrm{l}^{-1}\right)$, more typical of surface waters in grassland areas. It is likely that this may represent recharge prior to afforestation. 
Hydrochemical heterogeneity in the soils, streams and groundwaters of the Plynlimon forested catchment, Wales
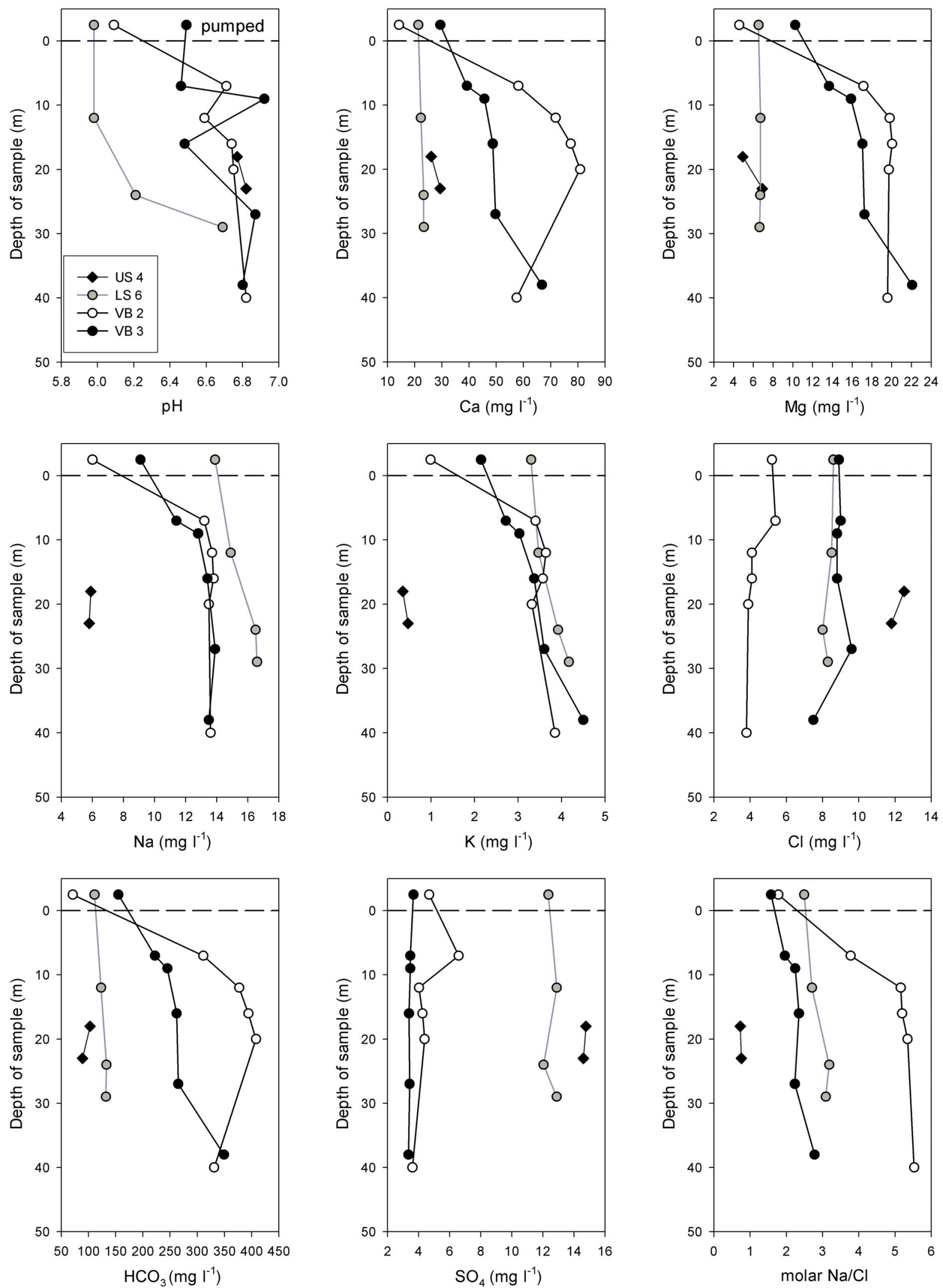

Fig. 12. Hydrochemical data for depth samples and pumped discharge (plotted above the zero scale on the y-axis) for deep boreholes. 
Trace element concentrations also varied in the deep borehole groundwaters. Those in the valley bottom had higher concentrations of $\mathrm{Fe}$ and $\mathrm{Mn}$ reflecting more reducing conditions. In addition, many other elements, including $\mathrm{Br}$, $\mathrm{I}, \mathrm{Be}, \mathrm{B}, \mathrm{Co}, \mathrm{Ni}, \mathrm{Sr}, \mathrm{Y}$ and $\mathrm{B}$, were higher in the valley bottom groundwaters. The lower slope borehole LS 6 contained higher $\mathrm{Li}$ and $\mathrm{B}$ as well as higher $\mathrm{Na}$ and $\mathrm{SO}_{4}$ and lower $\mathrm{pH}$.

\section{Variations with depth of borehole}

Selected groundwater chemical data, including the shallow boreholes, are plotted against depth of borehole in Fig. 13. The shallow boreholes displayed a wider range of temperature than the deep boreholes and were more dilute. In the shallow groundwaters, $\mathrm{pH}$ increased with depth (Fig. 13) and reached maxima at around $15 \mathrm{~m}$. These characteristics point to increasing residence time with depth. Limited dissolved oxygen (DO) measurements showed that the shallow groundwaters varied from oxidising to reducing conditions $\left(\mathrm{DO}<0.1 \mathrm{mg} \mathrm{l}^{-1}\right.$ ). The deeper groundwaters all had DO concentrations $<0.1 \mathrm{mg} \mathrm{l}^{-1}$ and precipitation of ferric hydroxides in sample bottles after collection confirmed that these waters were reducing.

The increase in SEC with depth is reflected in an increase in most major and minor elements including $\mathrm{Na}, \mathrm{Ca}, \mathrm{K}, \mathrm{Mg}$. $\mathrm{HCO}_{3}$ and Si. Sulphate and $\mathrm{Cl}$, however, showed greater variation spatially, rather than with depth (Fig. 13). The $\mathrm{SO}_{4} /$ $\mathrm{Cl}$ ratios in the valley bottom boreholes are close to those in average rainfall, although it is likely that some $\mathrm{SO}_{4}$-reduction has occurred (a smell of $\mathrm{H}_{2} \mathrm{~S}$ was noted). The higher $\mathrm{SO}_{4}$ groundwaters had high $\mathrm{SO}_{4} / \mathrm{Cl}$ ratios indicating an additional source of $\mathrm{SO}_{4}$, most likely from oxidation of pyrite in the Gwestyn Shales.

Depth variations were also found for the minor and trace elements: Fe and Mn were generally higher in the deeper groundwaters due to enhanced solubility under more reducing conditions. The gravel outcrops in the stream bed close to this site were found to be cemented with black manganiferous precipitates; this may indicate groundwater discharge to the river at this site. The trace elements $\mathrm{Al}, \mathrm{Be}$, $\mathrm{Cr}, \mathrm{Cu}$, La and $\mathrm{Y}$ tended to be higher in the shallow groundwaters, reflecting increased mobilisation under more acidic conditions, although $\mathrm{Ni}$ and $\mathrm{Co}$ increased with depth. A good correlation of the latter elements with Mn implies that reductive dissolution of Mn oxyhydroxide minerals may be the cause of the enhanced concentrations. Trace elements such as B, Li and Sr, which are considered good indicators of residence time, are highest in the deep boreholes and similar increases were observed for $\mathrm{Cs}$ and $\mathrm{Ba}$.

To summarise, there are distinct chemical differences between the boreholes in the upper slopes, lower slopes and valley bottoms. This shows that there are either differences in the mineralogy of the bedrock, that the residence times are different or that different geochemical processes are operative at the catchment scale. The groundwater in the deep boreholes is dominated by that of deeper fractures, but mixing with shallower fractures occurs in the pumped samples. It is likely that deeper groundwater discharges into the shallower fractures in the open boreholes when the borehole is not pumped, thus contaminating the shallow fractures. The shallower boreholes, therefore, provide better characterisation of the shallow groundwater than depth samples. The broad picture of increased TDS with depth in the shallow boreholes may also be complicated by mixing between different fractures due to variations in the temporal head in the groundwater at different depths. Temporal variations in chemistry may help to highlight if this is the case.

\section{Temporal variations in the shallow groundwaters}

The shallow boreholes were monitored monthly for a year to ascertain temporal variations. These data, along with water level data (Fig. 11) show that the groundwaters respond seasonally to rainfall inputs. The monitoring frequency is too low to assess changes during individual storm events but recent work has shown that responses are very rapid on the lower slopes (Haria and Shand, 2004). Time series data are shown on Figs. 14 and 15 along with stream flow in the Afon Hafren.

The shallow groundwaters varied from acidic to slightly acidic (Fig. 14) with a tendency for lower $\mathrm{pH}$ during the winter months. The increase in overall solute concentrations towards the lower slopes and valley bottom is also apparent in the time series data. The upper slope boreholes (US 1 and US 3) close to the edge of the forest tend to have low $\mathrm{Na}$ and $\mathrm{Cl}$ concentrations (although US 2 is similar to the other boreholes). Borehole US 1 (2.7 m depth) showed a large increase in $\mathrm{Cl}$ after the highest rainfall period probably reflecting a short residence time ( $\mathrm{Cl}$ tends to be higher during winter rainfall) or scavenging of sea-salt at the forest edge. However, the $\mathrm{Cl}$ concentrations are strongly damped compared to rainfall.

The high groundwater $\mathrm{SO}_{4}$ concentrations noted in the lower and intermediate slope boreholes are also confirmed in these samples, in particular in boreholes IS 2 and LS 2. Higher $\mathrm{SO}_{4}$ was present in the groundwaters during baseflow conditions (Fig. 15), implying a bedrock rather than rainfall source. Concentrations of $\mathrm{Ca}, \mathrm{Mg}, \mathrm{K}, \mathrm{Si}$, alkalinity, $\mathrm{Sr}$ and $\mathrm{Na} / \mathrm{Cl}$ are also higher in summer, suggesting a significant rock-derived input. However, many of the groundwaters show much smaller variations in solute chemistry over time. The temporal variations in some boreholes, and the different 
Hydrochemical heterogeneity in the soils, streams and groundwaters of the Plynlimon forested catchment, Wales
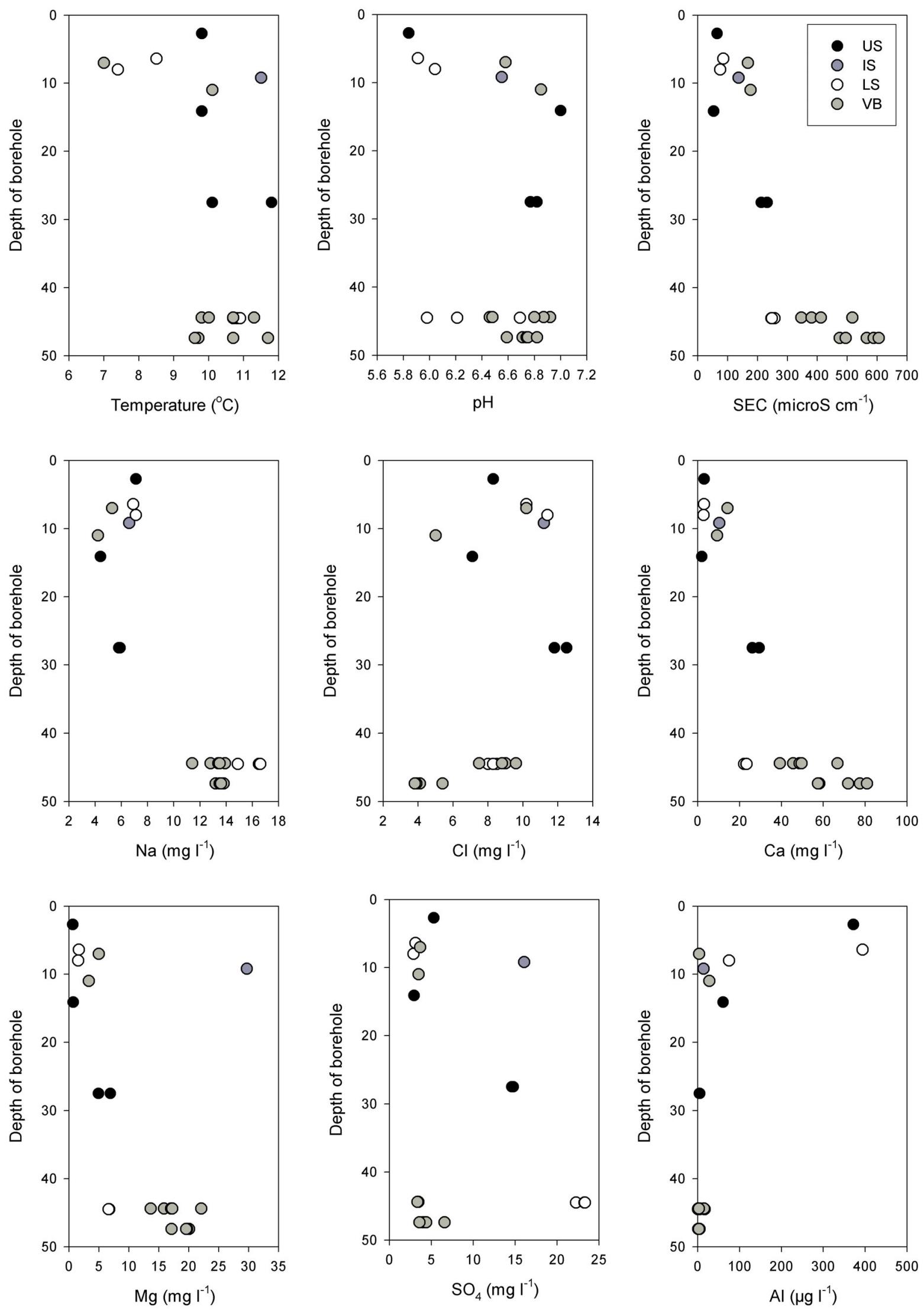

Fig. 13. Hydrochemical data and solute concentrations for deep and shallow boreholes plotted against borehole depth. 

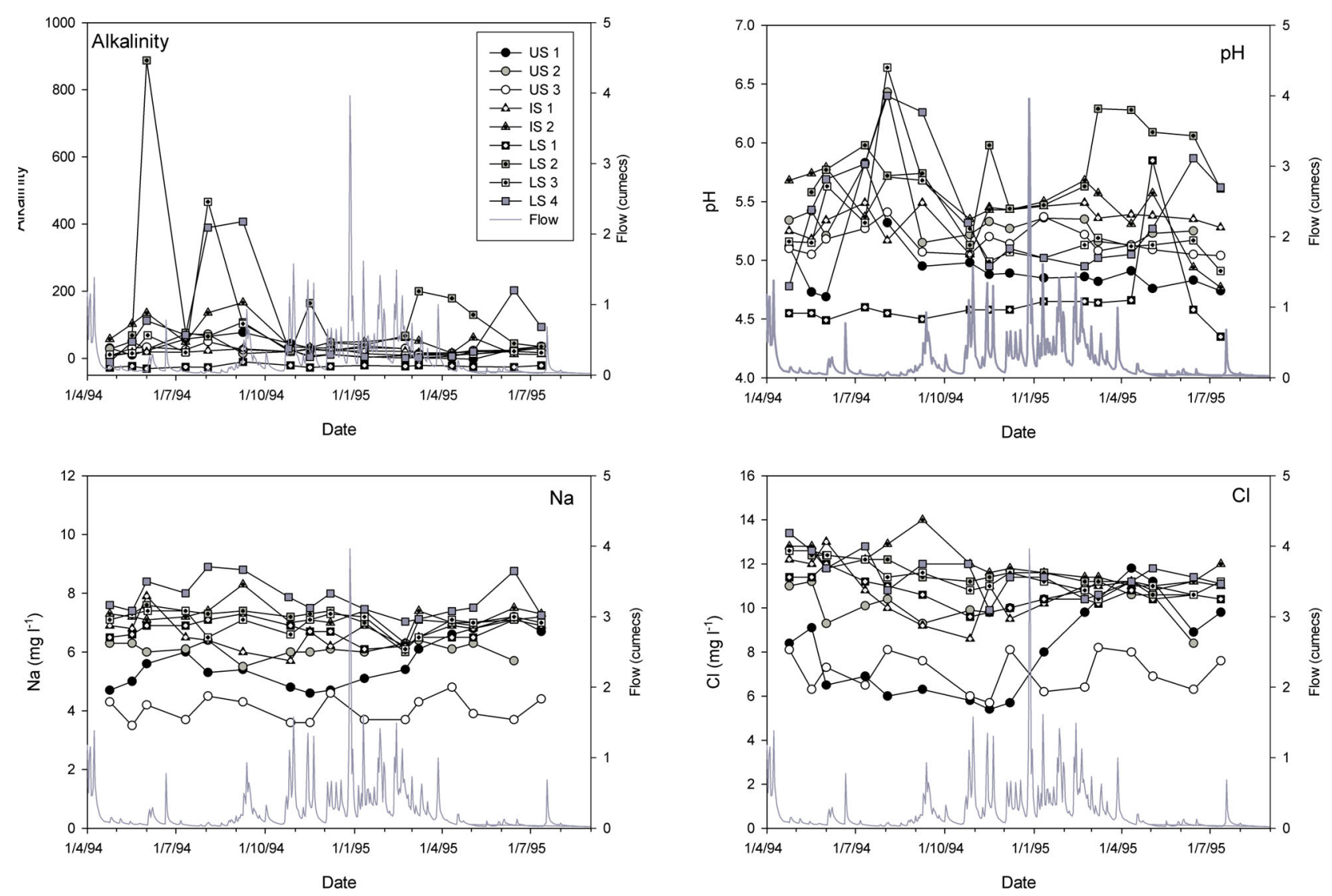

Fig. 14. Time series hydrochemical data for shallow boreholes in the Plynlimon catchment. Streamflow in the Afon Hafren catchment is shown for comparison and rainfall data and water level data are shown on Fig. 11 .

responses to rainfall indicate that considerable temporal heterogeneity exists in the groundwater (Hill and Neal, 1997; Neal et al., 1997b). The temporal variability may, in part, be due to mixing of groundwater from discrete shallow fractures where groundwater heads respond differently to recharge. Preliminary data from new piezometers sampling individual fractures show little temporal variation, providing some support for this conclusion (Shand et al., 2004).

\section{Discussion}

The wealth of hydrochemical data from the Plynlimon catchments has highlighted, in a small, relatively simple upland catchment, large spatial and temporal variations which can be interpreted in the context of variations in atmospheric inputs, geology, land use and residence time within a catchment. It may be that some of the previously reported variations in groundwater (Neal et al., 1997a) are a function of the sampling techniques used and borehole completion; therefore, care must be taken to sample the many discrete compartments which make up a catchment in three dimensions as well as in time.
Spatial variations in the hydrochemistry of waters are expected in response to residence time as well as to variations in source, land-use and atmospheric inputs. An assessment of these, as well as of temporal variations, is essential in modelling the response of catchments to environmental change. Although bulked parameter models are useful in predicting change, they often provide little information on actual flow processes or the time-scales involved. It is, therefore, necessary to have good high resolution data and knowledge of catchment functioning and flow pathways.

\section{SPATIAL VARIATIONS IN THE DIFFERENT CATCHMENT COMPARTMENTS}

Stream waters represent a bulked sample; the chemistry represents the end-product of chemical reactions, flowpathways, residence time and mixing within the catchment. Natural solutes, therefore, are a means of disentangling the history of the water from recharge through to the stream channel. Complications arise because sampling sub-surface flowpaths involves drilling which may modify the flow system. 

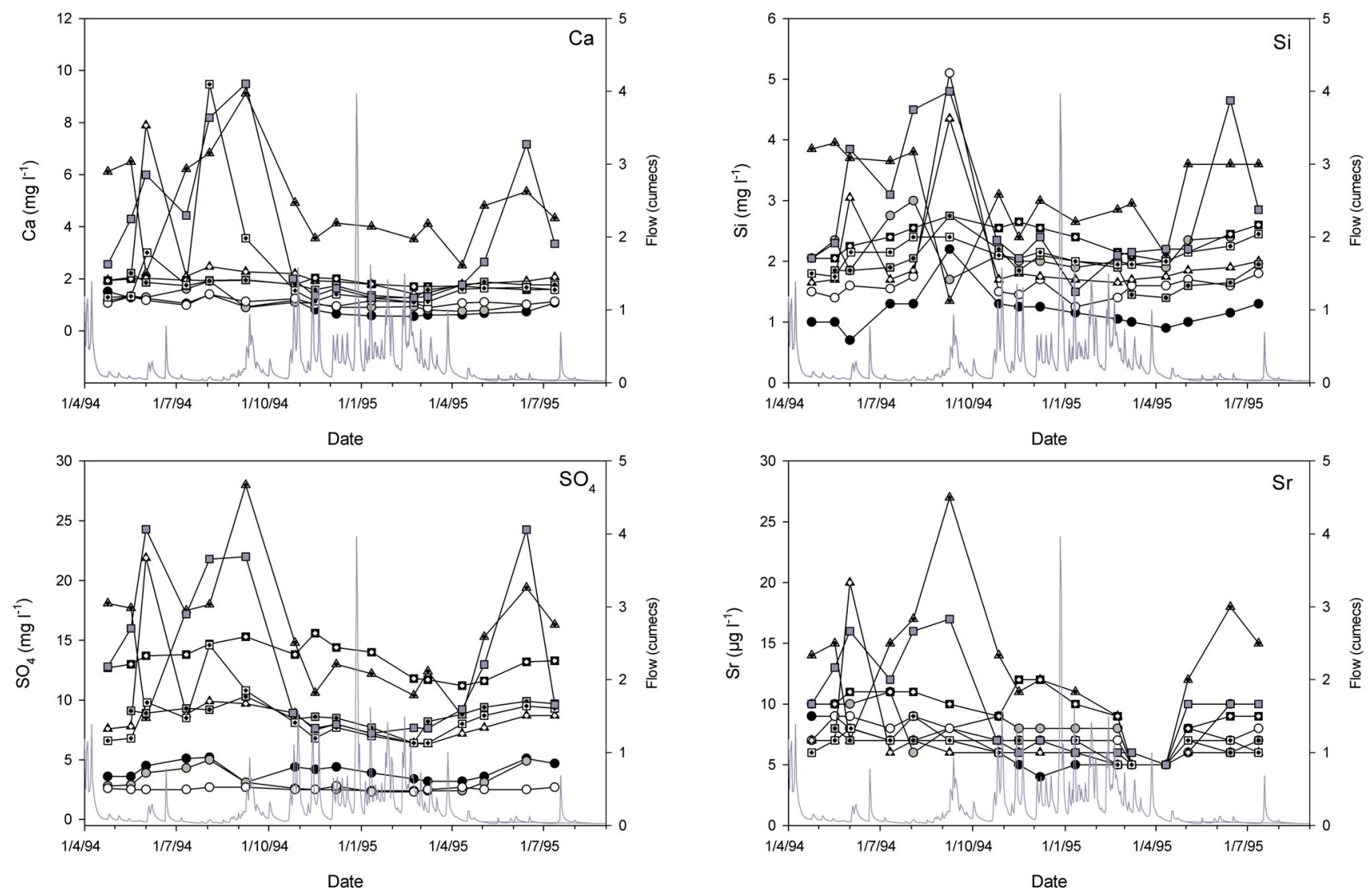

Fig. 15. Time series hydrochemical data for shallow boreholes in the Plynlimon catchment. Streamflow in the Afon Hafren catchment is shown for comparison and rainfall data and water level data are shown on Fig. 11.

The baseflow sampling of the Afon Hafren (Fig. 8) indicates significant changes in water chemistry along the stream; that major and trace solutes increase downstream is evidence of variable, continuous lateral inputs to the stream. The slightly higher SEC in the headwaters is most likely due to a contribution from organic acids since it is not reflected in the concentrations of inorganic solutes. The change to higher concentrations of many elements implies a change in source and/or residence time. Although the local effects of bedrock geology have not previously been considered a major factor in spatial variations, this change occurs close to the junction of the shales of the Ordovician Fan and the Silurian Gwestyn; the latter contains abundant pyrite $\left(\mathrm{FeS}_{2}\right)$ which can explain the higher $\mathrm{SO}_{4}$ as well as other solutes.

The changes in concentration with flow, as monitored at the flumes, are well established, showing that mixing during events is an important process. How these occur at a catchment scale, however, is poorly understood because of lack of good spatial data. Comparisons of baseflow and storm flow waters from across the Hafren and Wye catchments (Fig. 5) indicate that spatial patterns for some elements are robust, i.e. that the processes giving rise to spatial variations during baseflow are not swamped by the mixing of different waters during events. This evidence of the internal workings of the catchment implies consistency in its behaviour at a regional scale, making it easier to model such systems compared to a scenario of random behaviour and heterogeneity. Furthermore, it places constraints on the spatial variability of end-member compositions, a requirement for realistic mixing models and one which allows more detailed parameterisation of models and scaling effects to be considered.

The characterisation of potential end-members requires considerable amounts of data and careful sampling; unfortunately, few data are available on spatial variations in the soils of the Afon Hafren catchment, where most work was concentrated on specific solutes such as Al (Reynolds et al. 1986), $\mathrm{Cl}$ (Reynolds and Pomeroy, 1988) or N-species (Neal et al., 2004). Stevens et al. (1997) noted that ANC and $\mathrm{pH}$ varied with the age of forest stand in the Hafren forest, and that these were lower than in the moorland soils of Plynlimon. The soil porewater data (Fig. 3) highlight the strong vertical stratification in soils and the differences 
between soil types; their role in stream flow generation is difficult to establish by physical or chemical means and much further work is required. The presence of high $\mathrm{Al}$ and DOC in streams during storm events certainly implies a role for soils in stream flow generation but the lack of spatial data makes it difficult to attribute the changes in the stream to specific soil processes. Nevertheless, solute concentrations in the soils are similar to, or slightly higher than, those found in the streams.

The groundwater data help to build a picture of the chemical variations within the catchment. The shallow groundwaters are of low SEC and overlap with the soil water data. There are large chemical variations with depth and the concentrations of many solutes, especially those which typically increase with residence time (Ca, $\mathrm{Sr}, \mathrm{Mg}, \mathrm{Li}, \mathrm{B})$, are indicative of older waters in the deeper fractures. The deeper waters are also more reducing, with higher concentrations of those elements $(\mathrm{Fe}, \mathrm{Mn})$ that are more mobile under reducing conditions. In contrast, the low $\mathrm{pH}$ in many of the shallow groundwaters is reflected in high concentrations of trace elements which are more mobile under acidic conditions (e.g. Al, Be). The shallow bedrock is cased-off in most boreholes but shallow fractures may represent the dominant flow-path for groundwater in terms of streamflow generation. The limited interfluve data indicate a tendency for lower TDS waters in these areas. The deep groundwaters are probably relatively old (higher TDS, more reducing) but the chemistry is spatially variable (e.g. compare LS and VB boreholes, Fig. 12) across the catchment.

Temporal variations in water chemistry have been noted in some boreholes but, as these may intersect different fracture systems, potential mixing makes it difficult to interpret such patterns. Nevertheless, it is evident that there is a range of groundwater compositions in the catchment.

\section{SPATIAL VARIATIONS IN CHEMICAL WEATHERING}

The origin of dissolved solutes transported in rivers from catchments has been the subject of debate over the past few decades. Catchment mass balances have indicated the importance of atmospheric inputs but the origin of internal sources is more problematic. It is unclear whether stream solutes are derived from the shallow soils (particularly where acidic) where weathering is intense or from bedrock groundwater where weathering is often less intense but where volumes of stored water and residence times may be much higher.

Drift deposits in the Afon Hafren and Afon Hore catchments are of minor importance, and the unconsolidated soils are the product of chemical weathering and biological processes over the past 10000 years since the last glaciation. It is likely that afforestation has enhanced the weathering of soils through soil acidification and this is reflected in higher $\mathrm{Al}$ concentrations and the development of more extensive podzolisation in the forest. The spatial variations in soil type and development, from peats in the upper catchment, podzols on freely draining slopes and gleys in low lying valley bottoms, have given rise to large differences in soil chemistry (Fig. 3). The soils, typically acidic with low base cation concentrations, high DOC and $\mathrm{Al}$, reflect the unreactive nature of the bedrock minerals (dominantly illite and chlorite) and the lack of carbonate minerals. However, inputs of $\mathrm{Na}, \mathrm{Mg}$ and $\mathrm{Ca}$, particularly in the podzols, are indicated by elevated concentrations compared with the conservative element $\mathrm{Cl}$. Mass balance calculations of the soil data suggest that only a small proportion of $\mathrm{Na}$ and $\mathrm{Mg}$ are derived from weathering, whereas the bulk of $\mathrm{Ca}$ is derived from mineral weathering. The gley soils contained higher $\mathrm{Al}$ (porewater and exchangeable) but lower $\mathrm{Mg}, \mathrm{Na}$ and $\mathrm{Ca}$ than the podzols indicating that much of the cation pool has been removed by intensive leaching.

The $\mathrm{SO}_{4} / \mathrm{Cl}$ ratio is also higher than that in bulk precipitation but is more difficult to interpret due to lack of a detailed knowledge of dry deposition and atmospheric pollution inputs. Silicate weathering, considered to be the dominant process of weathering in the soils, is modified to a large degree by ion-exchange reactions involving $\mathrm{H}^{+}$and sea-salt inputs (Soulsby, 1995b). Inputs of many trace elements, including trace metals $\mathrm{Sr}$ and $\mathrm{Ba}$, are important indicators of weathering reactions but the fine-grained nature of the host minerals makes it difficult to ascertain specific reactions. Although the soils and soil waters represent the products of continued weathering, the role of soil water both as a direct contributor of solutes and to stream flow generation has been questioned (Shand et al., 1997, 2001).

The stream waters also indicate large spatial variations in weathering (Figs. 5 and 8). Large differences in stream water chemistry between the Severn forested and the adjacent Wye unforested catchments (Fig. 5) are related to the effects of atmospheric scavenging and differences in land use and in evapotranspiration. The near-linear trends for some elements (Fig. 5) and element/element ratios imply consistent variations in weathering, even during different flow regimes.

Much of the spatial variation is a reflection of previous $\mathrm{Pb}-\mathrm{Zn}$ mining activities particularly in the Wye Valley where the stream flows partly through mine adits and discarded waste material is present close to the stream channel. In the forested catchments, the Afon Hore stream contains higher Ca concentrations than the Afon Hafren. This was thought, previously, to be derived from mine waste but $\mathrm{Sr}$ isotope data has shown that much of the $\mathrm{Ca}$ is derived from silicate 
weathering, which may be more intense in the Hore than in the Hafren. The Hore has higher $\mathrm{Ca}$ and $\mathrm{pH}$ but much more $\mathrm{Al}$ in the stream; this may explain the absence of fish in the Hore, despite their presence in the more acidic Hafren (Crisp and Beaumont, 1997).

The more detailed reach study (Fig. 8) indicates consistent differences in weathering along the catchment. Ratios such as $\mathrm{Sr} / \mathrm{Ca}$ and $\mathrm{Mg} / \mathrm{Ca}$ indicate a change from rainfalldominated to weathering-dominated sources further downstream. The largest change in chemistry of stream waters occurred well within the confines of the Hafren forest which suggests that scavenging by marine aerosols is not the main cause for this increase. This is confirmed by the higher $\mathrm{Na} / \mathrm{Cl}$ ratios. The increase occurred at the junction between the Fan and Gwestyn Shales, upstream of which the bedrock forms hard competent beds, whereas the Gwestyn Shales were more fractured and contain pyrite. The oxidation of pyrite produces acidity which explains the lower $\mathrm{pH}$, and higher $\mathrm{SO}_{4}$ concentrations and $\mathrm{SO}_{4} / \mathrm{Cl}$ ratio downstream of the junction. The more intense fracturing, noted at outcrop, may also allow significant storage in the lower parts of the Hafren catchment. The reach study indicates two important conclusions: firstly, that inputs to the stream occur along the length of the catchment and secondly, that variations in weathering rate or residence time increase downstream.

The largest variations in catchment hydrochemistry were found in the groundwaters, both in terms of absolute concentrations and the relative proportions of major solutes (Figs. 12 and 13). Although no direct determinations have been made of groundwater age, the large increases in many major and trace elements indicate that the deepest groundwaters are much older than the shallow groundwaters. Many of the shallow groundwaters are acidic, resembling soil waters, and these probably represent very young waters. This is confirmed by the response of the shallow groundwaters to rainfall events.

Much of the acidity in the soil and shallow groundwaters has been neutralised in the deep groundwaters and weathering is much less intense. These deeper waters are high in $\mathrm{Ca}, \mathrm{Na}, \mathrm{K}$ and $\mathrm{Mg}$ as well as a range of minor and trace elements (Figs. 12-13). The origin of the excess (above the rainfall-derived signature) $\mathrm{Mg}$ and $\mathrm{K}$ is likely to be from the breakdown of chlorite and illite respectively. The excess $\mathrm{Na}$ (up to about twice the atmospheric contribution) may be from small amounts of feldspar or from ion-exchange sites. The high $\mathrm{SO}_{4}$ (up to $28 \mathrm{mg} \mathrm{l}^{-1}$ ) and $\mathrm{SO}_{4} / \mathrm{Cl}$ concentrations in some groundwaters are evidence of internal sources of $\mathrm{S}$. The presence of abundant fresh and partially oxidised pyrite $\left(\mathrm{FeS}_{2}\right)$ at outcrop is the most likely source for this excess $\mathrm{SO}_{4}$ and must be taken into account in models of S cycling and deposition.

The origin of $\mathrm{Ca}$ in many upland catchments has been an area of considerable debate; it is typically low in the bedrock (except in areas of vein mineralisation) and it has been suggested that the dominant control in many hard rock catchments is from small amounts of calcite, either in fractures or in the rock matrix (White et al., 2001). The rapid kinetics of calcite dissolution makes this feasible in many catchments, even where calcite is a minor component. Calcium is present at moderately high concentrations in the acidic soil waters of Plynlimon where calcite is absent. Although $\mathrm{Ca}$ and $\mathrm{HCO}_{3}$ concentrations are very high (e.g. $\mathrm{HCO}_{3}$ up to $408 \mathrm{mg} \mathrm{l}^{-1}$ ) in the valley bottom boreholes, the $\mathrm{pH}$ is low compared to waters buffered by calcite (c. 7.4), being more typical of buffering by silicate minerals. A silicate source is also consistent with $\mathrm{Sr}$ isotope data (Shand et al., 1999).

\section{THE ROLE OF GROUNDWATER IN STREAM FLOW}

\section{GENERATION}

Previous studies indicated the need to determine the role of groundwater in stream flow generation in the Plynlimon catchments (Neal et al., 1997a; Shand et al., 1997). Early models considered mixing of soil waters to produce the endmember compositions required but these failed to explain some of the hydrochemical characteristics of the stream waters. Two main issues arose with the detailed studies of catchment chemistry:

(1) stable isotopes and conservative solutes (e.g. $\mathrm{Cl}, \mathrm{Br}$ ) in streams displayed a very damped response relative to rainfall implying that there was enough storage in the catchments to damp the rainfall signal.

(2) baseflow chemistry was often more alkaline than that in soil waters (Neal et al., 1997b).

The higher alkalinities and ANC (Neal et al., 1997c) in stream water baseflow implied that the dominant source was not soil water. Earlier studies of groundwater considered that it was too complex to estimate end-members or to quantify groundwater inputs (Neal et al., 1997a; Hill and Neal, 1997).

The damped response in stream water $\mathrm{Cl}$ in the Plynlimon sub-catchments (Reynolds and Pomeroy, 1988; Neal and Rosier, 1990) was also difficult to explain by flowpaths through podzolic soils since damping of the highly variable atmospheric $\mathrm{Cl}$ inputs was much less than that found in the streams (Reynolds and Pomeroy, 1988). Mixing of soil water with event water would serve only to increase the $\mathrm{Cl}$ fluctuations in the streams. A study of stable isotopes $\left(\delta^{2} \mathrm{H}\right)$ in soil pipes in the Wye catchment by Sklash et al. (1996) indicated that, during high flow, much of the flow was pre- 
event, i.e. derived from rainfall which fell prior to the event being studied. This implied that the source of this water was well mixed and derived from an area with significant storage. While this well mixed source might be called 'groundwater' its location as sub-surface storage could not be determined, i.e. as deeper soil water or bedrock groundwater.

The presence of groundwater in all boreholes drilled into bedrock and the evidence for active groundwater circulation in fractures shows that the catchment is not sealed. Therefore, bedrock groundwater must be considered in catchment mass balances. The hydrochemical data for these groundwaters indicate that the concentrations of most solutes are generally higher than in the streams, although the streams overlap with shallow groundwaters. The high SEC and solute concentrations in the deeper groundwaters show that these are not dominant inputs to the streams even during baseflow conditions. However, the high heads found in many boreholes indicate that they may provide a minor, but important, input to soils, shallow groundwater and streams.

The chemistry of the shallow groundwaters varied from acidic with high $\mathrm{Al}$ to more alkaline with low $\mathrm{Al}$, covering much of the range of chemistry found in stream waters. The more acidic groundwaters are similar to soil waters, indicating little further reaction from that produced during percolation through the soils. There are large variations in groundwater chemistry with depth and it is possible that baseflow waters are derived from deeper fractures when groundwater levels are low and from stormflow waters derived from shallow fractures when water levels are high. Although this may explain some of the characteristics of stream waters under different flow regimes, it does not account for the very high stormflow Al and DOC concentrations, typical of the Plynlimon soils. These paradoxes need to be reconciled to explain the flowpaths and processes giving rise to the steam water chemistry.

The spatial variations in baseflow chemistry of the Afon Hafren (Fig. 8) indicate that the chemistry of the source changes along the entire reach of the catchment. There is little evidence of similar differences in the soils. Many of the stream and shallow groundwater samples overlap and lie on a trend between rainfall and deeper groundwater on a Piper plot (Fig. 16), but they are offset from soil waters which again suggests a limited direct role for soil waters in the streams. The limited groundwater data show changes in groundwater chemistry similar to that seen in the rivers between the headwaters and further downstream, albeit with higher concentrations. The problems of sampling groundwater in open boreholes complicate interpretation but it is likely that more dilute groundwaters are present in the shallowest fractures (Fig. 13). More detailed study of the shallow fractures across the catchment is, therefore, required to assess such variations in the shallow fractured bedrock.

Some of the clearest evidence for source inputs to the streams comes from natural tracers such as $\delta^{2} \mathrm{H}, \mathrm{Cl}$ and ${ }^{87} \mathrm{Sr} /$ ${ }^{86} \mathrm{Sr}$. The damping effect of rainfall variations in the conservative tracers $\delta^{2} \mathrm{H}$ and $\mathrm{Cl}$ in stream waters indicates significant storage. Mixing processes within the catchment must also be highly efficient to buffer the variable inputs. It is difficult using $\delta^{2} \mathrm{H}$ without detailed temporal analyses to determine whether this store occurs in the soils or bedrock. The strong damping of $\mathrm{Cl}$ in streams and groundwaters has not been observed in ferric podzol soil waters (Reynolds and Pomeroy, 1988) but data are available for podzol soils alone and damping may be more prevalent in peat soils (Soulsby and Reynolds, 1992). Strontium isotope studies (Shand et al., 2001, 2004) have shown that stream waters are most easily interpreted as shallow groundwater formed by mixing of rainfall and deeper groundwater, with a minor role for flow directly from peat and organic horizons.

The apparent contradictions in different types of data must be explained if an internally consistent model for catchment functioning is to be provided. The isotope and $\mathrm{Cl}$ data imply a significant residence time of waters in the catchment, at least sufficient for damping to occur, but solutes such as $\mathrm{Al}$ and DOC imply that mixing between end-members is important during events. Care needs to be taken in relating the source of solutes to the source of the water itself using non-conservative tracers such as $\mathrm{Al}$ and DOC. Shand et al. $(1997,2001)$ suggested that the high values of Al and DOC can be explained by the discharge of a well-mixed shallow groundwater through soils to the streams and mobilisation of these elements from soils in areas where the water table is close to the surface, i.e. in the lower slopes of the valleys (Fig. 11) or in the riparian zones of the river. Detailed site studies at Plynlimon (Shand et al., 2004) indicate that groundwater immediately beneath the soils is very acidic $(\mathrm{pH}<5)$ and has the capacity to leach Al during upward flow and discharge. Dilution of $\mathrm{Al}$ in streams has been noted during very large storm events once the soils have become thoroughly saturated; in such cases, it is likely that peat flow or rapid delivery of rainfall via overland flow are dominant.

The presence of a groundwater reservoir, albeit spatially variable, can help to explain the apparent contradictions between the behaviour of conservative and non-conservative elements in streams under different flow regimes. The role of alluvial gravels in many parts of the catchment is unknown but this may be an important area of storage and buffering. Nevertheless, the shallow highly-fractured bedrock may provide storage large enough to damp the highly variable solute inputs from rainfall, yet low enough and with transmissivity high enough to explain the rapid response of 


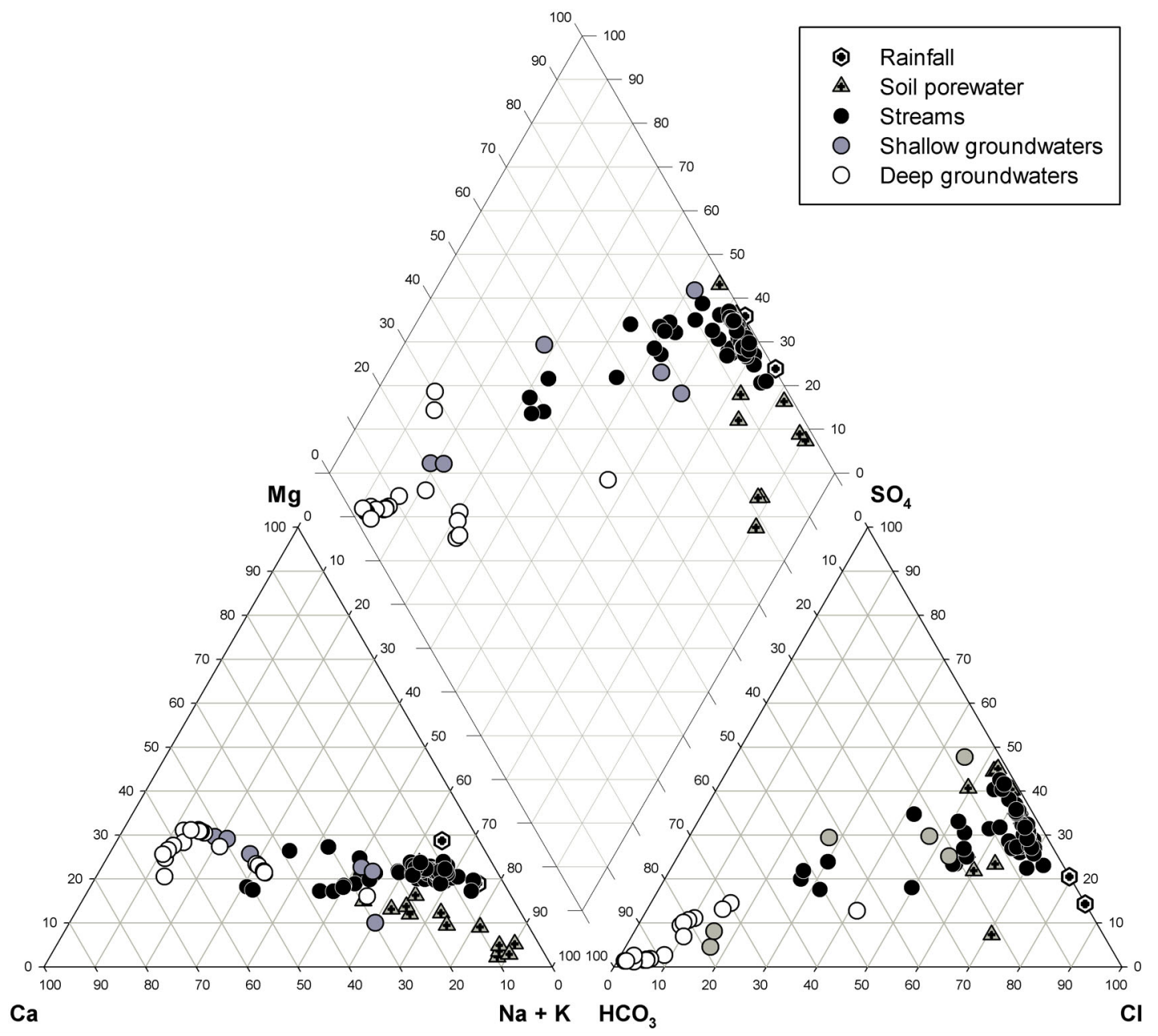

Fig. 16. Piper plot showing the relative proportions of major cations and anions in rainfall, soil porewaters, streams and groundwater of the Plynlimon catchment.

the catchment to rainfall. It is unlikely that the thin, often clay-rich soils can provide either sufficient storage to explain the required damping effects or the high transmissivity to explain the rapid responses in the catchments as well as the hydrochemical characteristics. The soils are important both as a flow pathway and as a major area of weathering, but it is suggested that soil drainage and macropore flow into the transmissive bedrock occur en route to the streams.

Detailed plot scale studies (Haria and Shand, 2004; Shand et al., 2004) indicate that the groundwater response to rainfall events is at the scale of a few hours. This implies rapid recharge, via bypass or macro-pore flow (Beven and Germann, 1982) into a highly transmissive network of fractures. The combination of outcrop observations, hydrochemical studies and geophysical logging have been used to provide an initial conceptual model of the functioning of the catchment (Fig. 17). The driving head for regional groundwater flow is from the upper slopes towards the valley bottom. The artesian conditions and high heads noted in deeper fractures in the boreholes in the valley bottom and lower slope indicate upward heads close to the river. Hence, at a regional scale, this upland fractured aquifer behaves like more permeable catchments. The hydrochemistry supports the geophysical log data (Fig. 10), implying a hydrologically active system at shallow depth which contains short residence time groundwater. However, there are as yet insufficient data to model the flow and transfer of water during recharge and discharge to the stream. It is envisioned that rapid recharge, via soil by-pass flow, causes the displacement of 'older' water from the bedrock during storm events. However, mixing is likely to vary spatially and with time according to antecedent conditions, fracture density and connectivity and rainfall amount and intensity. The implication of this study for other catchments is difficult to assess, as each catchment is unique in terms of its geological history and the presence of fractured 


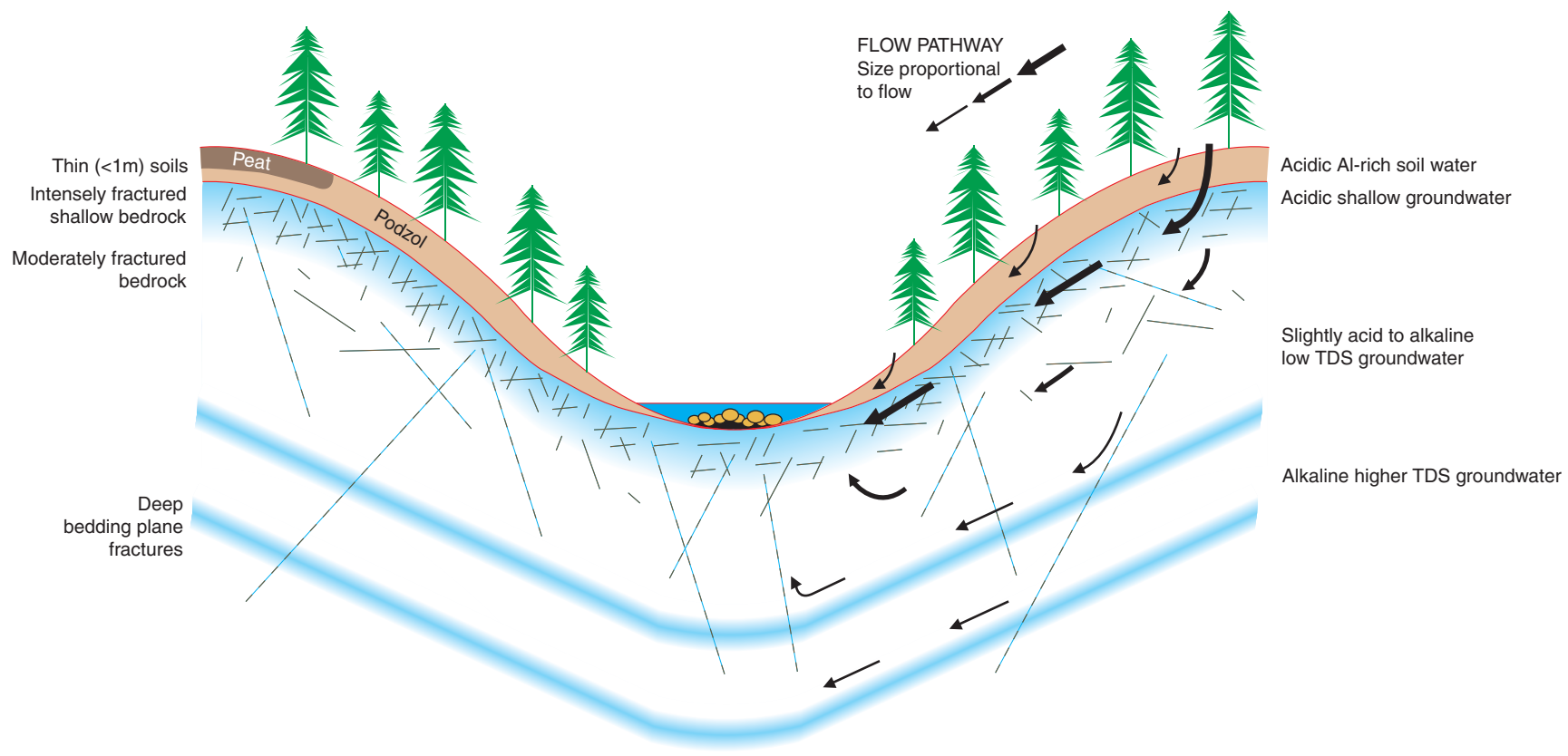

Fig. 17. Schematic diagram showing the dominant sub-surface flowpaths in the Plynlimon catchment.

bedrock beneath the soils is essential. The presence of groundwater in numerous catchments of similar geology in Wales (Shand et al., 2005) implies that groundwater is likely to form at least a component of streamflow. The Plynlimon catchment is a managed forest catchment, in which recharge processes may have been modified by enhancing macropore flow. However, preliminary groundwater data from the adjacent grassland Wye catchment indicates a strong similarity in the functioning of this catchment. In detail, the interactions between soil and groundwater with regard to flow and solute fluxes are still poorly understood.

\section{Summary}

The presence of an active bedrock groundwater system shows that it needs to be considered in terms of water balance and as a component in models of streamflow generation. Hydrochemical data from soils, streams and groundwater show a large degree of heterogeneity at all scales; this must be taken into account in models of catchment functioning. However, there are consistent spatial patterns of chemistry within the catchment, especially for the streams and groundwater. The spatial variations of all catchment compartments remain poorly understood in detail, but are critical to an understanding of flow and solute cycling through the catchment. The changes along the reach of the Afon Hafren indicate that the storage and/or residence times (as well as bedrock lithology) vary along the length of the catchment.
To explain the apparent contradictions between different conservative and non-conservative natural tracers, it is suggested that the fractured bedrock may represent the dominant flow pathway through the catchment. More detailed work is, however, required on groundwater levels and their responses to rainfall inputs and hydrogeological quantities such as storage and transmissivity. The detailed links between soils and groundwater in terms of recharge, flow paths and discharge are as yet poorly understood and need to be monitored at a level sufficient to measure the very rapid responses to rainfall, so typical of this upland catchment. The age of the groundwater also needs to be established, both in relation to depth and location, to establish the residence times and flow pathways of water from the recharge to the discharge areas of the groundwater. Fractured aquifers are inherently heterogeneous (Cook, 2003) presenting new challenges to modelling upland catchments. The Plynlimon catchments, despite several decades of research, continue to provide exciting and fundamental challenges to an understanding of upland 'impermeable' catchments.

\section{Acknowledgements}

The authors are grateful to Prof. Chris Soulsby for a very thorough and thought provoking review. The paper is published with permission of the Director of the British Geological Survey. 


\section{References}

Beven, K. and Germann, P., 1982. Macropores and water flow in soils. Water Resour. Res., 18, 1311-1325.

Buckley, D.K., 2000 Some case histories of geophysical downhole logging to examine borehole site and regional groundwater movement in Celtic regions. In: Groundwater in the Celtic Regions: Studies in Hard Rock and Quaternary Hydrogeology, N.S. Robins and B.D.R. Mistear (Eds.) Geological Society, London, UK. Special Publications, 182, 219-237.

Burns, D.A., McDonnell, J.J., Hooper, R.P., Peters, N.E., Freer, J.E., Kendall, C. and Beven, K., 2001. Quantifying contributions to storm runoff through end-member mixing analysis and hydrologic measurements at the Panola Mountain Research Watershed (Georgia, USA). Hydrol. Process., 15, 1903-1924.

Chappell, N.A., Ternan, J.L., Williams, A.G. and Reynolds, B., 1990. Preliminary analysis of water and solute movement beneath a coniferous hillslope in Mid-Wales, U.K. J. Hydrol., 116, 201-215.

Christopherson, N., Clair, T.A., Driscoll, C.T., Jeffries, D.S., Neal, C. and Semkin, R.G., 1994. Hydrochemical studies. In: Biogeochemistry of small catchments: A tool for environmental research, B. Moldan and J. Cerny (Eds.), Wiley, Chichester, UK.

Christopherson, N., Neal, C., Hooper, R.P., Vogt, R.D. and Andersen, S., 1990. Modelling streamwater chemistry as a mixture of soilwater end-members - A step towards seconedgeneration acidification models. J. Hydrol., 116, 307-320.

Cook, P.G., 2003. A guide to regional groundwater flow in fractured rock aquifers. CSIRO, Land and Water, Glen Osmond, Australia. $108 \mathrm{pp}$.

Cresser, M.S., Edwards, A.C., Ingram, S., Skiba, U. and PearsonSmith, T., 1986. Soil-acid deposition interactions and their possible effects on geochemical weathering rates in British Uplands. J. Geol. Soc. London, 143, 649-658.

Crisp, D.T. and Beaumont, W.R.C., 1997. Fish populations in Plynlimon streams. Hydrol. Earth Syst. Sci., 1, 541-548.

Genereux, D.P. and Hooper, R.P., 1998. Oxygen and hydrogen isotopes in rainfall-runoff studies. In: Isotope Tracers in Catchment Hydrology, C. Kendall and J.J. McDonnell (Eds.), Elsevier, Amsterdam, The Netherlands.

Gooddy, D.C., Shand, P., Kinniburgh, D.G. and Van Riemsdijk, W.H., 1995. Field-based partition coefficients for trace elements in soil solutions. Eur. J. Soil Sci., 46, 265-285.

Grossman, J. and Udluft, P., 1991. The extraction of soil water by the suction-cup method: a review. J. Soil Sci., 42, 83-93.

Haria, A. and Shand, P., 2004. Evidence for deep sub-surface flow routing in forested upland Wales: Implications for contaminant transport and stream flow generation. Hydrol. Earth Syst. Sci., 8, 334-344.

Hill, T. and Neal, C., 1997. Spatial and temporal variations in $\mathrm{pH}$, alkalinity and conductivity in surface run-off and groundwater for the upper River Severn catchment, mid-Wales. Hydrol. Earth Syst. Sci., 1, 687-696.

Hooper, R.P., Christopherson, N. and Peters, N.E., 1990. Modelling streamwater chemistry as a mixture of soilwater end-members - An application to the Panola Mountain catchment, Georgia, U.S.A. J. Hydrol., 116, 321-343.

Hornung, M., Adamson,, J.K., Reynolds, B. and Stevens, P.A., 1986. Influence of mineral weathering and catchment hydrology on drainage water chemistry in three upland sites in England and Wales. J. Geol. Soc. London, 143, 627-634.

Kirby, C., Newson, M.D. and Gilman, K.,1991. Plynlimon Research: The first two decades. Institute of Hydrology Report No. 109, Wallingford, UK.
Kirchner, J.W., Feng, X. and Neal, C., 2001. Catchment-scale advection and dispersion as a mechanism for fractal scaling in stream tracer concentrations. J. Hydrol., 254, 82-101.

Litaor, M.I.,1988. Review of soil solution samplers. Water Resour. Res., 24, 727-733.

Mather, J. D., 1985. Hydrogeological characterisation of potential radioactive waste repository host rocks at two research sites in the United Kingdom. Memoir 18th Congress, Int. Assoc. Hydrogeologists, 3, 159-167.

McDonnel, J.J., 2003. Where does water go when it rains? Moving beyond the variable source area concept of rainfall-runoff response. Hydrol. Process., 17, 1869-1875.

McGlynn, B., McDonnell, J.J. and Brammer, D., 2002. A review of the evolving perceptual model of hillslope flowpaths at the Miamai catchment, New Zealand. J. Hydrol., 257, 1-26.

Mulder, J. and Cresser, M.S., 1994. Soil and soil solution chemistry. In: Biogeochemistry of Small Catchments: A Tool for Environmental Research, B. Moldan and J. Cerny (Eds.) Wiley, Chichester, UK. 107-131.

Muscutt, A.D., Reynolds, B. and Wheater, H.S., 1993. Sources and controls of aluminium in storm runoff from a headwater catchment in Mid-Wales. J. Hydrol., 142, 409-425.

Neal, C., 1997. Introduction to the Special Issue of Hydrology and Earth System Sciences, the water quality of the Plynlimon catchments. Hydrol. Earth Syst. Sci., 1, 385-388.

Neal, C. and Rosier, P. 1990 Chemical studies of chloride and stable oxygen isotopes in two conifer afforested and moorland sites in the British uplands. J. Hydrol., 115, 269-283.

Neal, C., Reynolds, B., Neal, M., Wickham, H., Hill, L. and Williams, B. 2004 The impact of conifer harvesting on stream water quality: the Afon Hafren, mid-Wales. Hydrol. Earth Syst. Sci., 8, 503-520.

Neal, C., Robson, A.J., Shand, P., Edmunds, W.M., Dixon, A.J., Buckley, D.K., Hill, S., Harrow, M., Neal, M. and Reynolds, B., 1997a. The occurrence of groundwater in the Lower Palaeozoic rocks of upland Central Wales. Hydrol. Earth Syst. Sci., 1, 3-18.

Neal, C., Wilkinson, J., Neal, M., Harrow, M., Wickham, H., Hill, L. and Morfitt, C., 1997b. The hydrochemistry of the headwaters of the River Severn, Plynlimon. Hydrol. Earth Syst. Sci., 1, 583617.

Neal, C., Smith, C.J., Walls, J., Billingham, P., Hill, S. and Neal, M., 1990. Hydrochemical variations in Hafren forest stream waters. J. Hydrol., 116, 185-200.

Newson, M.D., 1976. The physiography, deposits and vegetation of the Plynlomon catchments. Institute of Hydrology Report No. 30, Wallingford, UK.

Reynolds, B, Neal, C., Hornung, M. and Stevens, P.A., 1986. Baseflow buffering of streamwater acidity in five mid-Wales catchments. J. Hydrol., 87, 167-185.

Reynolds, B. and Pomeroy, A.B., 1988. Hydrogeochemistry of chloride in an upland catchment in Mid-Wales. J. Hydrol., 99, 19-32.

Robson, A.J., Neal, C., Hill, S. and Smith, C.J., 1993. Linking variations in short and medium term stream chemistry to rainfall inputs - some observations at Plynlimon, mid-Wales. J. Hydrol., 144, 291-310.

Shand, P., Abesser, C., Farr, G., Wilton, N., Lapworth, D.J., Gooddy, D.C., Haria, A. and Hargreaves, R., 2005. Baseline Report Series: 17. The Ordovician and Silurian metasedimentary aquifers of central and south-west Wales. British Geological Survey Commissioned Report No. CR/05/034N.

Shand, P., Darbyshire, D.P.F. and Gooddy, D.C., 1999. The application of Sr isotopes to catchment studies: The Plynlimon upland catchment of Central Wales. British Geological Survey Report, WD/99/56. 
Shand, P., Darbyshire, D.P.F., Gooddy, D.C., Darling, W.G., Neal, C., Haria, A.H. and Dixon, A.J., 2001. The application of Sr isotopes to catchment studies: The Plynlimon upland catchment of Central Wales. In: Water-Rock Interaction 10, R. Cidu (Ed.) Balkema, Rotterdam, The Netherlands. 1577-1580.

Shand, P., Darbyshire, D.P.F., Gooddy, D.C., Edmunds, W.M. and Neal, C., $1997 .{ }^{87} \mathrm{Sr} /{ }^{86} \mathrm{Sr}$ as an indicator of flowpaths and weathering rates in the Plynlimon experimental catchment, Wales, U.K. J. Conf. Abst., 2, 296.

Shand, P., Edmunds, W.M., Wagstaff, S., Flavin, R. and Jones, H.K., 1999. Hydrogeochemical Processes Determining Water Quality in Upland Britain. Hydrogeology Report Series of the British Geological Survey, Keyworth, Nottingham. ISBN 0-85272314-8.

Shand, P., Griffiths, K., Darbyshire, D.P.F., Haria, A.H. and Davies, J., 2004. Streamflow generation in upland impermeable catchments - is there a need to think deeper? In: Water-Rock Interaction 11, R. B. Wanty and R.R. Seal (Eds.), Balkema, Rotterdam. 1391-1395.

Sklash, M.G., Beven, K.J., Gilman, K. and Darling, W.G., 1996. Isotope studies of pipeflow at Plynlimon, Wales, UK. Hydrol. Process., 10, 921-944.

Soulsby, C., 1992. Hydrological controls on acid runoff generation in an afforested headwater catchment at Llyn Brianne, MidWales. J. Hydrol., 138, 431-448.
Soulsby, C., 1995a. Contrasts in storm event hydrochemistry in an acidic afforested catchment in upland Wales. J. Hydrol., 170, 159-179.

Soulsby, C., 1995b. Influence of sea-salt on stream water chemistry in an upland afforested catchment. Hydrol. Process., 9, 183196.

Soulsby, C. and Reynolds, B., 1992. Modelling hydrological processes and aluminium leaching in an acid soil at Llyn Brianne, Mid-Wales. J. Hydrol., 138, 409-429.

Soulsby, C., Chen, M., Ferrier, R.C., Helliwell, R.C., Jenkins, A. and Harriman, R., 1998. Hydrogeochemistry of shallow groundwater in an upland Scottish catchment. Hydrol. Process., 12, 1111-1127.

Stevens, P.A., Reynolds, B., Hughes, S., Norris, D.A. and Dickinson, A.L., 1997. Relationships between spruce plantation age, solute and soil chemistry in Hafren forest. Hydrol. Earth Syst. Sci., 1, 3-18.

Suarez, D.L., 1987. Prediction of $\mathrm{pH}$ errors in soil water extractions due to degassing. Soil Sci. Amer. J., 51, 64-68.

Wade, A.J., Neal, C., Soulsby, C., Langan, R.P. and Cresser, M.S., 1999. Modelling streamwater quality under varying hydrological conditions at different spatial scales. J. Hydrol., 217, 266-283.

White, A.F., Schulz, M.S., Vivit, D.V. and Bullen, T.D., 2001. Disseminated calcite in a global suite of granitic rocks: Correlations with experimental solutes. In: Water-Rock Interaction, 10, R. Cidu (Ed.). 435-438. 